\title{
A evolução da carga tributária na Província de São Paulo, \\ 1835-1889.
}

\section{The evolution of the tax burden in the Province of São Paulo, 1835-1889.}

\section{Camila Scacchetti \\ Luciana Suarez Lopes}

Universidade de São Paulo

\section{Resumo}

Através da análise documental das Leis Orçamentárias e dos Relatórios de Presidente de Província, compreendendo os anos de 1835 a 1889 , este trabalho busca demonstrar a evolução histórica da estrutura tributária na Província de São Paulo, levando em consideração aspectos históricos, econômicos e políticos existentes na região em meados do período imperial. A evolução das novas formas de tributos que foram criadas no decorrer do tempo envolve a elevação dos valores orçados e a concentração de expectativa de arrecadação em determinados tributos.

Palavras-chave: Finanças públicas; Província de São Paulo; Brasil Império.

\section{Abstract}

Through the documentary analysis of the Budget Laws and the Reports of the President of the Province, covering the years 1835 to 1889 , this work seeks to demonstrate the historical evolution of the tax structure in the Province of São Paulo, taking into account the historical, economic and political aspects of the region in the middle of the imperial period. The evolution of the new forms of taxes that have been created over time involves the increase of budgeted amounts and the concentration of expectation of collection in certain taxes.

Keywords: Public finances; São Paulo Province; Brazil Empire. 


\section{Dossiê \\ História Econômica
Demografia Histórica}

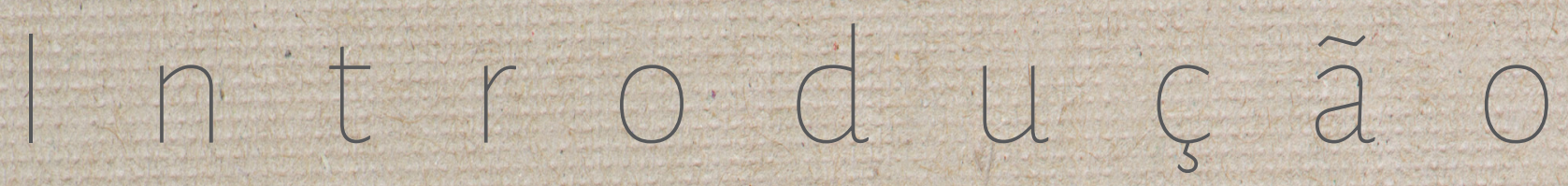

ntender a dinâmica tributária na Província de São Paulo no período imperial constitui elemento fundamental para compreendermos a atual carga tributária do Estado de São Paulo. Com base na análise de fontes documentais primárias, o presente artigo busca identificar a composição da receita tributária paulista e sua evolução durante todo o período, a partir da constituição da Assembleia Legislativa Provincial. Para isso, temos como principal fonte de dados as Leis Orçamentárias provinciais paulistas e os Relatórios de Presidentes de Província.

Nas Leis Orçamentárias, publicadas regularmente pela Assembleia, podemos encontrar as expectativas de receita e despesa para cada ano fiscal, assim como o registro das receitas e despesas especiais, tais como aquelas relacionadas às estradas e caminhos. Já nos Relatórios de Presidente de Província, o cotidiano descrito nos permite a compreensão das dificuldades, anseios, déficits e superávits provinciais, tornando mais concreta uma realidade que, para nós, é muitas vezes tão distante e abstrata.

Desta forma, constituem objetivos do presente artigo analisar o comportamento da expectativa de arrecadação tributária na Província de São Paulo entre 1835 e 1889, identificando suas principais fontes de renda orçadas, assim como sua evolução ao longo dos anos ${ }^{1}$. Sendo assim, compõem este artigo, além da introdução, outras quatro seções. A primeira dedica-se à discussão, ainda que breve, do contexto econômico da Província de São Paulo nos momentos iniciais do período estudado. A segunda seção dedica-se à análise e acompanhamento das leis orçamentárias paulistas até o final do período imperial. A fim de complementar as análises feitas na segunda seção, a terceira parte do texto utiliza como fonte de dados os Relatórios de Presidente de Província. Ao final, algumas considerações encerram a discussão.

\section{A Província de São Paulo, c. 1835}

Em 12 de agosto de 1834, entrava em vigor a lei de número dezesseis, mais conhecida como Ato Adicional. Elaborado com o intuito de ceder um pouco de controle aos defensores do fe-

1 A pesquisa em questão encontra-se em andamento, sendo apresentado neste artigo o resultado acerca das informações extraídas das leis orçamentárias paulistas. Em trabalhos futuros, por intermédio da análise dos balanços provinciais e das prestações de contas, será possível averiguar se os valores orçados se confirmaram. 
deralismo, o Ato teve como uma de suas alterações mais substanciais a criação de órgãos legislativos regionais, as Assembleias Legislativas Provinciais². Dentre as várias atribuições das Assembleias, estava o controle e elaboração das contas, balanços e orçamentos provinciais, além da criação dos impostos necessários ao seu financiamento³.

Logo no ano seguinte, outra lei também de número dezesseis foi promulgada pelo então presidente provincial Rafael Tobias de Aguiar. O teor da lei era simples. Fruto de um projeto elaborado pelos primeiros congressistas paulistas, previa a elaboração de um minucioso levantamento estatístico, cujo financiamento seria feito por meio de uma verba de $600 \$ 000$ aprovada por lei posterior (SYLOS, 1978, p. IX). O encarregado seria o marechal Daniel Pedro Müller, e até hoje o resultado deste levantamento constitui referência seminal para aqueles dedicados ao estudo da economia paulista oitocentista4.

O relato de Müller não deixa dúvidas de que a Província de São Paulo, durante a primeira metade do século XIX, constituía um verdadeiro mosaico de contextos econômicos e sociais. Em algumas partes de seu território, a cultura cafeeira avançava, trazendo consigo a promessa do desenvolvimento econômico; em outras, a tradicional cultura da cana-de-açúcar absorvia grande parte dos recursos; e em todas, com maior ou menor intensidade, havia a lavoura dedicada à produção de gêneros de subsistência, assim como a criação de gado e pequenos animais. Essa diversidade de atividades colocava as freguesias, vilas e cidades até então existentes em diferentes níveis de desenvolvimento econômico.

Ainda segundo o marechal, no momento de seu levantamento a Província contava com 326.902 habitantes, distribuídos por 46 vilas. Desses, $73,4 \%$ eram livres e $26,6 \%$ cativos $^{5}$. Como foi mencionado anteriormente, era grande a importância da chamada indústria agrícola. Conforme a Tabela 1, dentre os produtos mais comuns, destacam-se o arroz, o café, o feijão, a aguardente e o milho. Aolado destes, outros 22 gêneros ou produtos foram localizados, dentre

2 Logo após a Independência, o país passa por um longo período de discussões em torno da conformação de seu novo arcabouço institucional. Como resultados, podemos citar a conturbada promulgação da Constituição em 1824, e a elaboração do Ato Adicional, já no período das Regências. Não constitui objetivo do presente artigo analisar as várias interpretações da historiografia acerca desse período, mas como referências introdutórias sobre o tema, ver Miriam Dolhnikoff $(2005 ; 2003)$ e Ivo Coser (2008).

3 Ademais, ainda considerando o tema das finanças públicas, competia às Assembleias controlar as finanças municipais, de modo a terem se tornado as Câmaras Locais órgãos de caráter meramente administrativo. Sobre essa questão, afirmou Montoro (1974, p. 12); "portanto, bastante claro que, ao atender aos ideais de autonomia das Províncias, ideia central do movimento federalista, o Ato Adicional impediu o desenvolvimento da autonomia municipal".

4 Todavia, há que se ressaltar que o minucioso trabalho não ficou livre de alguns erros e incorreções, principalmente nas estimativas agregadas, fruto da consolidação das várias listas nominativas utilizadas como subsídio para a publicação de 1838. Sobre essas incorreções, ver o texto de Francisco Vidal Luna (2002).

5 Os números foram calculados considerando-se como livres todos os indivíduos classificados por Müller (1978, p. 169) como índios. 
os quais podemos citar o toucinho, a erva-mate e a batata, além de al guns produtos manufaturados, tais como os tecidos de algodão, as telhas de barro, a rapadura, o carvão e a marmelada. Segundo os relatos, as técnicas de cultivo e produção eram simples, baseando-se na constante destruição de matas e nas queimadas como forma de limpar os terrenos. A utilização de arados era pouco comum, sendo encontrado apenas em algumas vilas açucareiras.

Nesta Província pouco se trabalha com os animais, para prontificação das terras; apenas começa o uso do arado em algumas chácaras e engenhos de açúcar; tudo é feito à força de braços de homens com foice, machado e enxada (MÜLLER, 1878, p. 29).

Sobre as finanças paulistas, dada a recente criação da Assembleia Legislativa, o marechal limitou-se a apresentar os números referentes ao ano financeiro 1835-1836, além de descrever quais eram os impostos arrecadados pelas repartições provinciais e de que forma era feito 0 recolhimento 6 .

Tabela 1 - Produção Total da Província de São Paulo, 1836.?

\begin{tabular}{|c|c|c|c|}
\hline Produto & Quantidade & Produto & Quantidade \\
\hline Café & 588.136 arrobas & Rapaduras & 46.300 unidades \\
\hline Açúcar & 563.108 arrobas & Pano de algodão & 600 varas \\
\hline Aguardente & 46.728 canadas & Chá & 1.970 libras \\
\hline Arroz & 341.220 alqueires & Telhas & 92.000 unidades \\
\hline Farinha de mandioca & 79.765 alqueires & Marmelada & 30 arrobas \\
\hline Feijão & 237.116 alqueires & Batatas & 92 alqueires \\
\hline Milho & 3.870 .020 alqueires & Farinha de milho & 2.451 alqueires \\
\hline Azeite de amendoim & 666 medidas & Trigo & 26 alqueires \\
\hline Fumo & 11.773 arrobas & Cabras & 10 unidades \\
\hline Algodão em rama & 9.282 arrobas & Erva Mate & 485.881 arrobas \\
\hline Cal & $1.232,5$ moios & Vigas & 1.623 unidades \\
\hline Taboados & 2.087 dúzias & Embé & 2.480 unidades \\
\hline Peixe seco & 4.060 arrobas & Canoas & 100 unidades \\
\hline Porcos & 69.158 unidades & Chapéus & 310 unidades \\
\hline Gado cavalar & 71.400 unidades & Esteiras & 198 dúzias \\
\hline Gado muar & 2.268 unidades & Embaúva & 40 arrobas \\
\hline Gado vaccum & 35.573 unidades & Carvão & 70 medidas \\
\hline Gado lanígero & 5.799 unidades & Ripas & 110 dúzias \\
\hline Toucinho & 12.990 arrobas & Valor total & $4.766: 918 \$ 493$ \\
\hline
\end{tabular}

Fonte: $\operatorname{Müller}(1978$, p. 129).

6 Além dos impostos provinciais, Müller (1978, p. 209-213) apresenta também os impostos gerais que eram arrecadados na Província. Contudo, optamos por não os apresentar, considerando serem os impostos provinciais nosso objetivo primordial. Sobre os impostos gerais recolhidos pelos cofres provinciais, consultar a mencionada obra de Müller, em especial a Tabela 9.

7 Sobre as unidades de medida utilizadas no Brasil dos séculos XVIII e XIX, ver os textos de Iraci del Nero da Costa (1994) e Francisco Vidal Luna e Herbert Klein (2001). 
Segundo o registro de Müller eram recolhidos pelas autoridades da província um total de dezesseis impostos provinciais; além de mais quatro pertencentes à renda geral do Império8, de forma a fazer parte da receita provincial paulista as seguintes imposições?:

- Novos e velhos direitos: instituído em 1832, era recolhido sobre as Provisões, Diplomas e Papéis Forenses, sendo isentos de tal cobrança os funcionários das Tesourarias, Alfândegas, Mesas de Rendas, professores públicos, professores de cursos jurídicos, juízes de direito ejuízes municipais, além dos empregados militares e da Marinha. Cobrado pelos Coletores.

- Novos impostos: criado como forma de financiar a reconstrução da alfândega de Lisboa depois do terremoto de 1755 , acabou sendo utilizado para pagamento de oficiais de $2 a$. linha e posteriormente para obras públicas. Era proveniente de várias cobranças: imposição de $6 \$ 400$ réis aos armazéns da cidade e vilas de serra acima, dos gêneros miúdos que passam no Cubatão para a vila de Santos; cobrança de $4 \$ 000$ das tabernas da mesma vila; cobrança de $\$ 320$ por uma besta, $\$ 200$ por um cavalo e $\$ 100$ por uma cabeça de gado vacum que passam no registro de Sorocaba. Cobrado por coletores.

- Subsídio literário: estabelecido em 1772 em benefício da instrução pública. Cobrança de $\$ 820$ de toda e qualquer rês morta e comercializada. Cobrado por coletores.

- Carne verde: imposição instituída em 1809 e modificada em 1835, previa a cobrança de $1 \$ 600$ de toda rês morta e comercializada. Cobrada por coletores.

- Dízimos: cobrança sobre os gêneros exportados para fora da província, sendo a alíquota de $10 \%$ aplicada sobre os gêneros agrícolas e a de $5 \%$ aplicada sobre os gêneros manufaturados; com exceção dos dízimos sobre açúcar, café, algodão, tabaco e fumo, além do gado vacum e cavalar, quando estes fossem exportados para fora do Império. Cobrados nas alfândegas em Santose Paranaguá, e por coletores nas demais partes da província.

- Décima dos prédios urbanos: cobrado desde 1808/1809 nas vilas com cem casas ou mais. Cobrada por coletores.

- Décima dos legados e heranças: cobrança imposta em 1809; consistia em cobrar 10\% dó valor dos bens deixados a herdeiros que não fossem ascendentes ou descendentes e da quinta parte de toda a herança abintestada sendo parente até segundo grau. Cobrada por coletores.

- Direitos do Rio Negro: cobrança instituída em 1747 , consistindo em pagar $2 \$ 500$ por cada burro ou besta; $2 \$ 000$ porcada cavalo e $\$ 960$ réis por cada égua que se criam além dos limites da província até o Registro. Cobrado pelos coletores.

8 Os impostos pertencentes à renda geral eram aqueles registrados sob as rubricas alfândegas, chancelaria, selo, e correio (MÜLLER, 1978, p. 212-213).

9 Os levantamentos de Müller representam um importante ponto de partida para a pesquisa ora proposta e o entendimento das questões tributárias na Província de São Paulo no início do século XIX. Em boa medida, esses apontamentos reproduzem o conteúdo das primeiras leis orçamentárias da província, conteúdo esse que, com o passar dos anos, foi sofrendo algumas modificações que serão discutidas no decorrer deste artigo. 
- $20 \%$ da aguardente de consumo: cobrança instituída em 1835 , sobre o consumo de qualquer aguardente-nacional ou estrangeira. Cobrado pelos coletores.

- Meia sisa dos escravos ladinos: pagamento de $5 \%$ do preço de venda do escravo. Quando a negociação envolvia a troca de um escravo por outro, a cobrança recaía apenas sobre os valores em espécie que porventura fizessem parte da negociação. Cobrado pelos coletores.

- Foros e arrendamentos: pagamento de algum foro, ou aluguel dos bens de raiz pertencentes à Fazenda Pública. Cobrado pelos coletores.

- Emolumentos da secretaria: cobrança de $1 \$ 920$ réis do registro das patentes de confirmação e decretos, além de $\$ 960$ réis do registro das provisões e portarias das secretarias de estado, e mesmo valor de quaisquer certidões. Cobrados nas competentes repartições.

- Tipografia: cobrança pelas folhas remetidas às Câmaras e pela impressão de obras de particulares. Cobrada pelos administradores.

- Despachos de embarcações: taxas que pagam os passaportes das embarcações, tanto nacionais como estrangeiras. Cobrados pela Secretaria do Governo.

- Prisão com trabalho: produto do trabalho ou de produtos produzidos pelos presos. Cobrança feita com base nos registros do Administrador.

- Contribuição para Guarapuava: criada em 1809 para custear as despesas com a expedição e conquista dos campos de Guarapuava. Arrecadada por meio de taxas diversas sobre animais: $\$ 875$ por cada muar arreado desde Curitiba até Sorocaba; $\$ 750$ por cada cavalo e $\$ 240$ por cada cabeça de gado vacum. Se criadas no Sul, Serra de Vacaria, e Lages, era cobrado $\$ 160$ por cada besta e $\$ 220$ por cada cavalo. Cobrada pelo coletor da vila de Sorocaba.

A arrecadação dessas rendas era feita por meio dos Coletores, Administradores, Juízes, Tesouraria, Alfândegas e mesas de diversas rendas, que enviavam ao Tesouro o montante líquido das quantias arrecadadas.

Além da descrição das diversas rendas arrecadadas pela Província, Müller também apresenta o Resumo do Balanço da Receita e Despeza da Província no Último Anno Financeiro ${ }^{10}$. Nele, aparecem as mencionadas fontes de renda, assim como os montantes arrecadados e dispendidos no exercício financeiro correspondente ao período de $1^{\circ}$ de julho de 1835 a 30 de junho de 1836 . Como podemos observar na Tabela 2, porcentagem considerável da receita provincial advinha da cobrança pela passagem de animais do Rio Negro, dos dízimos e das receitas eventuais. Essas três rubricas foram responsáveis por mais da metade do total arrecadado.

10 Optamos, sempre que possível, por manter a ortografia de época tanto nas citações ao longo do texto como na elaboração das tabelas, cujo conteúdo busca reproduzir as informações constantes das Leis Orçamentárias. 


\section{História Econômicag Dossiê}

Tabela 2-Resumo do Balanço da Receita Provincial. São Paulo, 1835-1836.

\begin{tabular}{lrr}
\hline Receita & Valor & $\%$ \\
\hline Dízimos & $31: 351 \$ 648$ & $10,7 \%$ \\
\hline $20 \%$ da aguardente & $9: 331 \$ 440$ & $3,2 \%$ \\
Novo imposto e dos animais em Sorocaba & $22: 074 \$ 216$ & $7,5 \%$ \\
\hline Décima dos prédios urbanos & $19: 053 \$ 703$ & $6,5 \%$ \\
Foros e arrendamentos & $778 \$ 354$ & $0,3 \%$ \\
\hline Carne verde e subsídio literário & $19: 170 \$ 442$ & $6,5 \%$ \\
Meia sisa dos escravos & $16: 475 \$ 977$ & $5,6 \%$ \\
Décima dos legados & $28: 010 \$ 910$ & $9,6 \%$ \\
Novos e velhos direitos & $1: 251 \$ 066$ & $0,4 \%$ \\
Emolumentos da secretaria & $154 \$ 120$ & $0,1 \%$ \\
Despachos de embarcações & $551 \$ 990$ & $0,2 \%$ \\
Contribuição de Cuarapuava & $9: 595 \$ 140$ & $3,3 \%$ \\
Animais do Rio Negro & $81: 869 \$ 950$ & $28,0 \%$ \\
Multas a mestres de barcos & $1: 816 \$ 282$ & $0,6 \%$ \\
\hline Passagens e rios & $7: 476 \$ 635$ & $2,6 \%$ \\
\hline Selo & $212 \$ 856$ & $0,1 \%$ \\
Imposto para o Banco & $1: 926 \$ 921$ & $0,7 \%$ \\
Casas de leilão & $40 \$ 000$ & $0,0 \%$ \\
\hline Tipografia & $690 \$ 250$ & $0,2 \%$ \\
Casa de prisão com trabalho & $225 \$ 699$ & $0,1 \%$ \\
\hline Aldeamento de Guarapuava & $249 \$ 960$ & $0,1 \%$ \\
Receita eventual & $38: 898 \$ 731$ & $13,3 \%$ \\
Dita não classificada & $1: 495 \$ 069$ & $0,5 \%$ \\
\hline Total & $292: 701 \$ 359$ & $100,0 \%$ \\
\hline & & \\
\hline
\end{tabular}

Fonte: Müller (1978, p. 215). ${ }^{11}$

As chamadas receitas eventuais aparecem aqui com a seguinte observação de Müller (1978, p. 215): "lei provincial de 11 d'Abril de 1835". O mencionado dispositivo legal é a Lei $n^{\circ} 17$, que "Marca a receita e fixa a despesa provincial para o ano financeiro de $1^{\circ}$ de julho de 1835 ao último de junho de 1836", e foi a primeira lei orçamentária aprovada pela Assembleia Legislativa, registrando em primeira mão as fontes de renda pertencentes à Província. Todavia, nela não aparece a rubrica receitas eventuais, o que nos leva a crer serem as tais receitas eventuais provenientes de arrecadações extintas ou que não haviam sido incorporadas na lei orçamentária de 1835, daí seu valor elevado.

Dessa forma, e partindo desse panorama geral de 1836 descrito por Müller, busca-se, no presente artigo, acompanhar a evolução dos orçamentos da província paulista no período 1835-1889.

11 Segundo Müller (1978, p. 215), na receita estavam incluídas as cobranças dos dois últimos anos, de 1833 a 1834 . Na rubrica passagens dos rios estavam incluídas as dívidas atrasadas, já abolidas na data da publicação pela lei provincial de março de 1836; a rubrica imposto para o Banço era referente a atrasados de exercícios anteriores; e a receita eventual era proveniente da lei de 11 de abril de 1835. 


\section{O que dizem as Leis Orçamentárias}

\section{O progresso da receita orçada no decorrer do XIX}

A documentação histórica disponibilizada no sítio da Assembleia Legislativa de São Paulo (Alesp) constitui a principal fonte de dados para a análise, compreensão e discussão de como se dava, no período imperial, a elaboração do orçamento da província paulista. Através do estudo das leis orçamentárias é possível observar as alterações que ocorreram ao longo do tempo, o comportamento da expectativa de arrecadação, a criação de novos impostos e a extinção de outros.

Contudo, antes de iniciarmos a análise das já mencionadas leis orçamentárias, algumas importantes considerações de caráter metodológico devem ser feitas. Buscando acompanhar a evolução da estrutura tributária da Província de São Paulo durante o Império, apresentamos na Tabela 3 uma síntese da receita orçada para todo o período em análise. Algumas lacunas foram inevitáveis, dada a não localização, até o presente momento, das respectivas leis orçamentárias ${ }^{12}$. Análises mais detalhadas das leis orçamentárias também foram elaboradas, mas para isso foram selecionados alguns anos, distribuídos ao longo de todo o período. A seleção desses anos obedeceu a alguns critérios. Em primeiro lugar, selecionamos a primeira e a última lei orçamentária promulgada pela Assembleia Legislativa no Império. Em seguida, selecionados leis intermediárias distribuídas ao longo deste intervalo, referentes ao ano inicial de cada década, o que resultou nas leis orçamentárias dos anos de 1840, 1850, 1860, 187.0 e 1880. A única exceção foi para o ano de 1860, pois dada a ausência de lei orçamentária para este ano, foi selecionada a lei orçamentária do ano seguinte, 1861. Ademais, torna-se pertinente esclarecer que, em todos os orçamentos considerados, 0 ano fiscal inicia em $1^{\circ}$ de julho e finda em 30 de junho do ano subsequente. Dessa forma, o orçamento para 1840 corresponde ao ano fiscal de $7^{\circ}$ de julho de 1840 a 30 de junho de 1841 ; o de 1850 corresponde a $1^{\circ}$ de julho de 1850 a 30 de junho de 1851 ; a lei orçamentária de 1861 abrange $1^{\circ}$ de julho de 1861 a 30 de junho de 1862 , e assim sucessivamente até 1889 , que engloba $1^{\circ}$ de julho de 1889 a 30 de junho de 1890 .

Outra questão de caráter metodológico a ser mencionada refere-se ao fato de que, em alguns momentos do texto, apresentamos a representatividade calculada de algum tributo na receita total. Nesses casos, o cálculo foi feito excluindo-se da receita total os valores arreca-

12 A pesquisa desenvolvida encontra-se em andamento. No decorrer das próximas etapas tais lacunas podem vir a ser preenchidas, podendo ser as informações faltantes incluídas em trabalho futuro. 


\section{História Econômicag Dossiê}

dados com as estradas e barreiras, por entendermos essas rendas como sendo de aplicação especial, pois necessariamente deveriam ser revertidas em obras e melhoramentos no primitivo sistema viário da província.

Dessa forma, como já mencionado anteriormente, a Tabela 3 traz uma síntese do valor total das receitas orçadas, cujos dados nos permitem verificar que houve uma significativa elevação em termos do total orçado pela província, o que certamente está vinculado ao próprio desenvolvimento econômico paulista observado no período. Os valores são apresentados também em libras esterlinas, estando sua evolução apresentada no Gráfico $1^{13}$.

Tabela 3 - Evolução da receita provincial orçada. São Paulo, 1835-1889.

\begin{tabular}{|c|c|c|c|}
\hline Ano & $\begin{array}{c}\text { Receita Orçada } \\
\text { (valores nominais) }\end{array}$ & $\begin{array}{c}\text { Receita orçada } \\
\text { (valores em libras esterlinas) }\end{array}$ & $\begin{array}{c}\text { Variação \% em relação ao período anterior } \\
\text { (em libras esterlinas) }\end{array}$ \\
\hline 1835 & 243.700 .000 & 39.846 & $2 .-18$ \\
\hline 1836 & 244.840 .000 & 39.218 & $-1,58 \%$ \\
\hline 1839 & 340.423 .062 & 44.834 & $14,32 \%$ \\
\hline 1840 & 365.684 .000 & 47.246 & $5,38 \%$ \\
\hline 1844 & 405.560 .000 & 42.583 & $-9,87 \%$ \\
\hline 1845 & 430.460 .000 & 45.629 & $7,15 \%$ \\
\hline 1850 & 486.450 .000 & 58.278 & $27,72 \%$ \\
\hline 1853 & 691.705 .000 & 82.101 & $40,88 \%$ \\
\hline 1854 & 547.600 .000 & 63.029 & $-23,23 \%$ \\
\hline 1857 & 1.057 .900 .000 & 117.206 & $85,96 \%$ \\
\hline 1861 & 1.116 .513 .590 & 718.905 & $1,45 \%$ \\
\hline 1862 & 1.329 .002 .300 & 145.644 & $22,49 \%$ \\
\hline 1864 & 1.314 .862 .400 & 146.650 & $0,69 \%$ \\
\hline 1866 & 1.199 .887 .000 & 120.483 & $-17,84 \%$ \\
\hline 1868 & 1.287 .400 .000 & 89.490 & $-25,72 \%$ \\
\hline 1870 & 2.430 .000 .000 & 224.356 & $150,71 \%$ \\
\hline 1871 & 1.500 .000 .000 & 150.150 & $-33,08 \%$ \\
\hline 1874 & 2.706 .772 .665 & 290.707 & $93,61 \%$ \\
\hline 1876 & 2.433 .052 .000 & $258.749^{\circ}$ & $-17,20 \%$ \\
\hline 1879 & 3.042 .432 .734 & 271.670 & $5,24 \%$ \\
\hline 1880 & 3.732 .371 .176 & 346.553 & $27,56 \%$ \\
\hline 1883 & 3.743 .460 .621 & 336.158 & $-3,00 \%$ \\
\hline 1884 & 3.263 .000 .000 & 281.269 & $-76,33 \%$ \\
\hline 1887 & 4.112 .500 .000 & 384.490 & $36,70 \%$ \\
\hline 1889 & 5.061 .120 .000 & 557.699 & $45,05 \%$ \\
\hline
\end{tabular}

Fonte: Leis orçamentárias paulistas (1835-1889).

13 Tal procedimento é necessário pois, no período 1835-1889, houve considerável.variação do poder aquisitivo da moeda nacional, em especial durante a Cuerra do Paraguai e durante o socorro às vítimas da seca de 1878 . Nessas ocasiões, a política monetária expansionista financiou os déficits do governo, fazendo crescer os níveis de inflação e alterando o poder aquisitivo externo da moeda nacional. 
Gráfico 1 - Evolução da receita provincial orçada. São Paulo, 1835-1889 (valores em libras esterlinas) ${ }^{14}$.

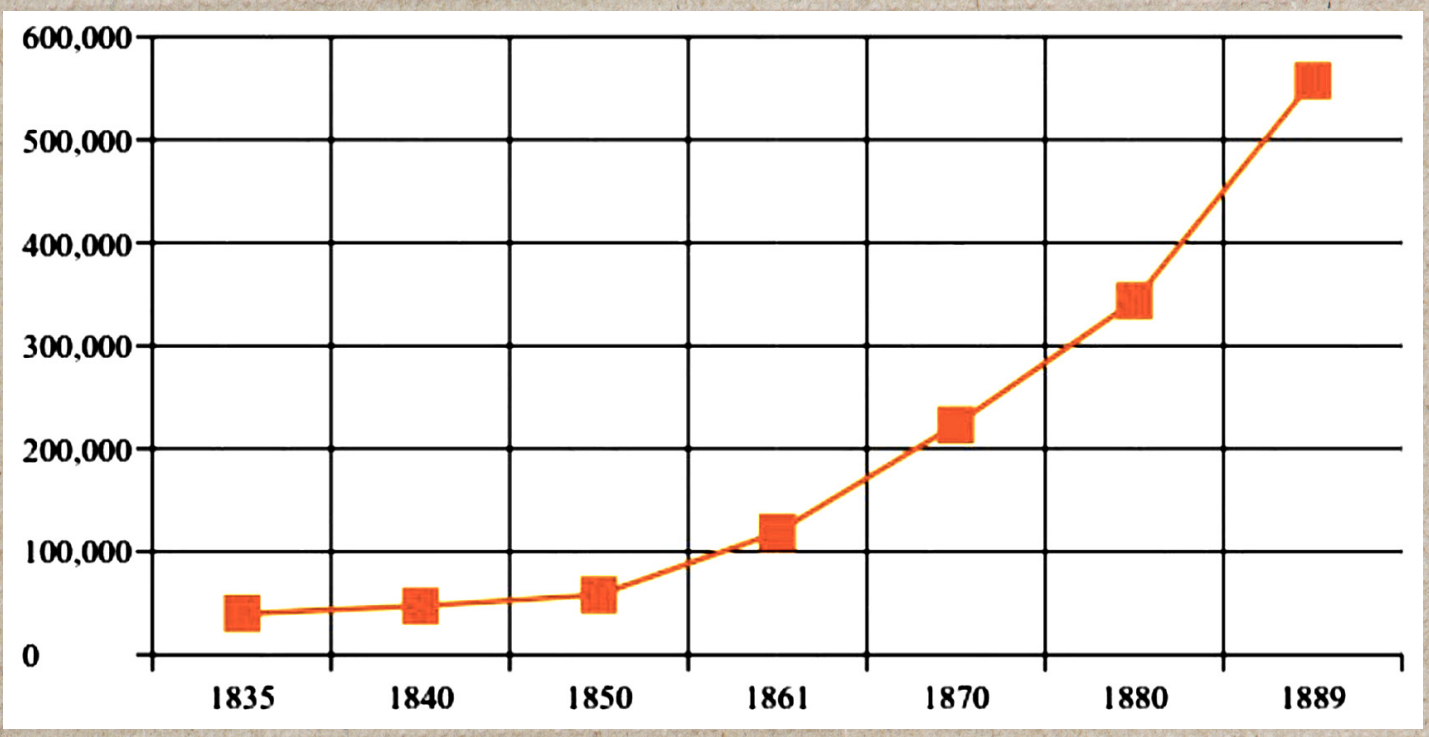

Fonte: Leis orçamentárias paulistas

O crescimento no anseio arrecadatório é evidente, ainda que existam variações significativas em alguns anos. Como exemplo, podemos destacar o ano de 1854, cuja receita orçada foi significativamente menor do que a do ano anterior, devido ao fato de a expectativa de arrecadação com as taxas de barreira ser menor, decorrente da diminuição do número de postos de cobrança, de doze para nove ${ }^{15}$. Outro exemplo é o ano de 1871 , em que a queda na expectativa da receita deveu-se à diminuição no provisionamento dos direitos de saída ${ }^{16}$.

Em boa medida, essa evolução constitui consequência natural do desenvolvimento econômico da província paulista nesse momento. A produção açucareira e, depois, a cultura cafeeira, desenvolveram-se rapidamente, em especial através do chamado complexo cafeeiro, característico da segunda metade do século.

Observando os valores em libras esterlinas, a receita paulista passa de $£ 39.846$ - valor orçado em 1835 - para $£ 557.699$ - valor orçado em 1889. Em termos percéntuais, isso significa um aumento de quase $1.300 \%$. Tal resultado, muito expressivo, merece nossa atenção. Dessa forma, a fim de melhor entendermos esse comportamento, faz-se necessária uma análise detalhada das principais fontes de renda da província paulista de então.

14 Optamos por utilizar a taxa de câmbio presente em Nozoe et al (2004), em que é indicada a série de taxa de câmbio implícita na praça do Rio de Janeiro, publicada no terceiro volume da série de estatísticas retrospectivas dọ IBGE.

15 Através das comparações entres as leis orçamentárias de 1853 e 1854, e da análise dos Relatórios de Presidente de Província, é possível observar que deixam de constar, na lei orçamentária de 1854, as barreiras do Rio do Pinto, Itoupava, Cracioza e Itararé. Na verdade, tais barreiras não foram desativadas, mas sim transferidas para a província do Paraná. Como forma de amenizar o desfalque sofridó pelas finanças paulistas criou-se, na lei orçamentária de 1854, a barreira de Itapetininga, localizada geograficamente próxima à barreira de Itararé.

16 Entre os anos de 1870 e 1871, França e Prússia entraram em guerra. Tal conflito foi sentido nas exportações brasileiras, em especial as da Província de São Paulo. A queda nas exportações prejudicou a arrecadação dos direitos de saída, promovendo a piora na expectativa de receita. Tais declarações são encontradas no Relatório de Presidente de Província (1870, p. 19). 


\section{História Econômicag Dossiê}

\section{As Leis Orçamentárias}

Conforme a Tabela 4, é possível observar que $28 \%$ da receita orçada concentra-se na expectativa de arrecadação nas estradas e $72 \%$ nas diversas formas de tributos. Dentre os tributos, os dois, mais expressivos são os dízimos (com a nomenclatura direitos de saída nas leis orçamentárias posteriores) e cobrança sobre a passagem dos animais no registro do Rio Negro. O primeiro contribui com pouco mais de $14 \%$ da soma das receitas (desconsiderando as receitas provenientes das estradas), enquanto o segundo colabora com quase $38 \%$. Portanto, $52 \%$ da expectativa de arrecadação de receitas estava concentrada em somente dois tributos (novamente desconsiderando as receitas das estradas), e os $48 \%$ restantes distribuídos em treze fontes de arrecadação.

Tabela 4 - Lei Orçamentária de 7835 - Ano financeiro de $7^{\circ}$ de julho de 1835 a 30 de junho de 1836.

\begin{tabular}{|c|c|}
\hline \multicolumn{2}{|l|}{ Receitas } \\
\hline $7^{\circ}$ - Importância dos Dízimos & $25.000 \$ 000$ \\
\hline $2^{\circ}$ - Dita da imposição de 20 por cento no consumo das agoas-ardentes de produção brasileira & $5.400 \$ 000$ \\
\hline $3^{\circ}$ - Dita do novo imposto, ou subsídio voluntário & $19.600 \$ 000$ \\
\hline $4^{\circ}$ - Dita da Decima dos prédios urbanos & $13.400 \$ 000$ \\
\hline $5^{\circ}$ - Dita de foros, e arrendamentos, de propios nacionaes & $600 \$ 000$ \\
\hline $6^{0}$ - Dita do imposto de $1 \$ 600$ rs por cada rez que se corta, na forma da lei provincial respectiva, e do de 320 rs de subsídio-literário & $14.000 \$ 000$ \\
\hline $7^{\circ}$ - Dita da meia siza da venda de quaisquer escravos & $9.000 \$ 000$ \\
\hline $8^{\circ}$ - Dita da decima dos legadós, e heranças & $5.400 \$ 000$ \\
\hline $\begin{array}{l}9^{\circ} \text { - Dita dos novos e velhos direitos dos títulos expedidos pelas autoridades provinciais, inclusivè a taxa que por este título pagão as fianças } \\
\text { criminais, a qual fica substituída pela taxa de } 2 \text { por cento da avaliação dellas }\end{array}$ & $2.000 \$ 000$ \\
\hline $10^{\circ}$ - Dita de emolumentos do Secretário do Coverno & $100 \$ 000$ \\
\hline $17^{\circ}$ - Dita dos despachos das embarcações & $400 \$ 00$ \\
\hline $12^{\circ}$ - Dita da contribuição para Cuarapuava & $5.000 \$ 000$ \\
\hline $13^{\circ}$ - Dita dos animaes no Registro do Rio Negro & $66.000 \$ 000$ \\
\hline $14^{\circ}$ - Dita do produto das multas sobre o Mestre de barcos & $400 \$ 00$ \\
\hline $15^{\circ}$ - Dita das passagens de rios & $9.200 \$ 00$ \\
\hline Somma & $175.500 \$ 000$ \\
\hline \multicolumn{2}{|l|}{ Rendas das Estradas } \\
\hline $7^{\circ}$ - Importância da contribuição da estrada de Santos & $36.000 \$ 000$ \\
\hline $2^{\circ}$ - Dita da de Parahibuna a Caraguatatuba & $5,00 \$ 000$ \\
\hline $3^{\circ}$ - Dita da de Coritiba para Morretes, e Antonina & $4.000 \$ 000$ \\
\hline $4^{\circ}$ - Dita da de S. José dos Pinhais para Morretes, afora os saldos e dívidas ativas dessa caixa, inclusive pela taxa sobre o gado, que tem descido & $2.000 \$ 000$ \\
\hline $5^{\circ}$ - Dita da do Registro do Banco de Area e outras quaisquer barreiras, que se estabeleça na estrada do Rio & $12.000 \$ 000$ \\
\hline $6^{\circ}$ - Dita do empréstimo autorizado para a estrada do Bananal & $4.000 \$ 000$ \\
\hline $7^{\circ}$ - Dita do dito para a de Arêas & $2.000 \$ 000$ \\
\hline $8^{\circ}$ - Dita do dito para a de S. Luiz & $2.000 \$ 000$ \\
\hline $9^{\circ}$ - Dita do dito para a de Parahibuna & $2.000 \$ 000$ \\
\hline $10^{\circ}$ - Dita do dito para a de S. Sebastião & $2.000 \$ 000$ \\
\hline $17^{\circ}$ - Dita do dito para a de Potunã & $700 \$ 000$ \\
\hline $12^{\circ}$ - Dita do dito para a de S. José dos Pinhaes & $1.000 \$ 000$ \\
\hline Somma & $68.200 \$ 00$ \\
\hline Somma Total & $243.700 \$ 000$ \\
\hline
\end{tabular}

Fonte: Tabela elaborada de acordo com a Lei $n^{\circ} 17$, de 11 de abril de 1835. Província de São Paulo (1835). 
Se considerarmos a soma total da receita orçada, os dízimos e os direitos de passagem dos animais no registro do Rio Negro respondem por aproximadamente 37\% das fontes de receita da Província. Faz-se importante registrar que na Lei Orçamentária de 1835 foram arroladas quinze fontes de renda, adicionando-se a essas as diversas rendas provenientes das estradas.

Tabela 5 - Lei Orçamentária de 1840 - Ano financeiro de $7^{\circ}$ de julho de 1840 a 30 de junho de 1847.

\begin{tabular}{|c|c|}
\hline \multicolumn{2}{|l|}{ Receitas } \\
\hline 70- Direitos de sahida da Província denominados dízimos & $100.000 \$ 00$ \\
\hline $2^{\circ}$ - Imposto sobre as aguas ardentes nacionais e estrangeiras & $16.000 \$ 000$ \\
\hline $3^{\circ}$ - Dito sobre os armazéns, tabernas e botequins de serra acima & $10.000 \$ 000$ \\
\hline $4^{\circ}$ - Novo imposto sobre os animais em Sorocaba & $8.000 \$ 00$ \\
\hline $5^{\circ}$-Contribuição para Cuarapuava & $6.200 \$ 000$ \\
\hline $6^{\circ}$ - Imposto de $1 \$ 600$ rs das rezes que se cortam e 320 rs de subsídio literário & $15.000 \$ 000$ \\
\hline $7^{0}-$ Meía siza da venda de escravos & $15.000 \$ 000$ \\
\hline $8^{\circ}$ - Décima dos legados e heranças & $8.000 \$ 000$ \\
\hline $9^{\circ}$ - Novos e velhos direitos provinciais & $2.000 \$ 000$ \\
\hline $10^{\circ}$ - Direitos do animais que passam pelo Rio Negro & $80.738 \$ 000$ \\
\hline $71^{\circ}$ - Emolumentos do lugar de secretário do Coverno & $150 \$ 000$ \\
\hline $12^{\circ}$ - Despacho das embarcações & $400 \$ 000$ \\
\hline $13^{\circ}-$ Imosto sobre as casas de leilão e modas & $200 \$ 000$ \\
\hline $14^{\circ}$ - Cobrança da metade da dívida ativa provincial anterior ao $1^{\circ}$ de julho de 1836 , e toda dívida ativa dessa data em diante & $24.800 \$ 000$ \\
\hline $15^{\circ}$ - Typographia provincial & $160 \$ 000$ \\
\hline $16^{\circ}$ - Juros das apolices compradas por conta do cofre provincial vencidos no corrente ano & $4.000 \$ 000$ \\
\hline $17^{\circ}$ - Renda eventual, multa sobre os contribuintes morosos e premio dos depositos públicos & $200 \$ 00$ \\
\hline Somma & $290.848 \$ 000$ \\
\hline \multicolumn{2}{|l|}{ Rendas das Estradas } \\
\hline $1^{\circ}$ - Barreira de Santos & $46.000 \$ 000$ \\
\hline $2^{\circ}$ - Dita de Ubatuba & $5.000 \$ 000$ \\
\hline $3^{\circ}$ - Dita de Caraguatatuba & $1.600 \$ 000$ \\
\hline $4^{0}$ - Dita de S. Sebastião & $100 \$ 000$ \\
\hline $5^{0}$ - Dita da Campina em Coritiba & $7.000 \$ 000$ \\
\hline $6^{\circ}$ - Dita do Arraial de S. José dos Pinhaes & $3.200 \$ 000$ \\
\hline $7^{0}$ - Dita do Banco de Arêa & $4.500 \$ 000$ \\
\hline $8^{\circ}$ - Dita do Taboão de Cunha & $2.000 \$ 000$ \\
\hline $9^{\circ}$ - Dita do Rio do Braço & $700 \$ 000$ \\
\hline $10^{\circ}$ - Dita do Ribeirão da Serra & $400 \$ 000$ \\
\hline $11^{\circ}$ - Dita do Rio da Onça & $400 \$ 000$ \\
\hline $12^{\circ}-$ Dita da Serra do Carioca & $400 \$ 000$ \\
\hline $13^{\circ}$ - Dita do Ariró & $400 \$ 000$ \\
\hline $14^{\circ}$ - Dita das Minhocas & $3.000 \$ 000$ \\
\hline $15^{\circ}$ - Dita das demais barreiras não especificadas & $100 \$ 00$ \\
\hline Somma & $74.800 \$ 000$ \\
\hline
\end{tabular}

Fonte: Tabela elaborada de acordo com a Lei n 17, de 26 de março de 1840. Província de São Paulo (1840).

Como mostra a Tabela 5, se comparada à Lei Orçamentária de 1835 , e considerando-se os valores em libras esterlinas, o total da receita orçada para o ano de $1840-1841$ cresceu $18,57 \%$. Contudo, em valores nominais, a participação das receitas provenientes das estradas caiu se 
comparada ao período anterior, passando de $28 \%$ para $20 \%$ do total orçado, ainda que seu valor, também nominal, tenha aumentado, passando de $68: 200 \$ 000$ para $74: 800 \$ 000$.

Dentre os $80 \%$ restantes, os direitos de saída e o direito dos animais que passam pelo Rio Negro continuam a constituir as principais fontes da receita orçada. Entretanto, o primeiro passou de uma participação de pouco mais de $14 \%$ no período inicial, para um peso aproximado de $35 \%$ neste momento (de 25:000\$000 para 100:000\$000). Já o segundo contribuiu, em 1840, com 28\% do orçado, sendo que, em 1835, representava 37\%. Desta forma, é possível constatar que, no período de meia década, os direitos de saída passam a ter maior importância dentre as fontes de arrecadação, tomando o lugar de vanguarda que antes era atribuído aos direitos de passagem de animais pelo Rio Negro. A soma dos direitos de saída e dos direitos de passagem de animais no Rio Negro totalizam, em 1840,62\% da expectativa da arrecadação (desconsiderando as receitas das estradas). Em 1835 tal montante correspondia a $52 \%$. A crescente participação que os direitos de saída passam a assumir a partir desta lei orçamentária, e que será mantida e elevada nas leis posteriores, é resultado da importância que o café, paulatinamente, adquire na economia paulista.

Ademais, ainda com relação aos impostos listados na Lei Orçamentária de 1840 , o novo imposto sobre os animais em Sorocaba representa, na verdade, apenas uma alteração de nomenclatura. Trata-se do novo imposto ou subsídio voluntário arrolado na Lei Orçamentária de 1835. O objetivo, quando da criação deste imposto, era oferecer auxílio financeiro para a reconstrução de Lisboa após o terremoto de 1755. Contudo, extirpado o prazo de 10 anos originalmente instituído, as rendas provenientes deste imposto eram destinadas para outros fins.

Ao retirar-se da análise as receitas orçadas provenientes da cobrança da dívida ativa (24:800\$00), typographia (160\$000), juros das apólices ( $4: 000 \$ 000)$ e multas $(200 \$ 000)$, chegamos a um provisionamento total de 336:524\$000, que corresponde a uma elevação de $38 \%$ da carga tributária e direitos de passagens nas estradas em relação a 1835.

Como visto anteriormente, com o passar dos anos a receita orçamentária paulista continua a apresentar tendência crescente. A análise comparativa entre os valores, em libra esterlina, referentes às leis orçamentárias de 1840 a 1850 , mostra que houve um crescimento de $23,35 \%$. Analisando de maneira mais detal hista, os valores nominais de cada uma das fontes de renda são apresentados na Tabela 6.

A receita orçada oriunda das rendas das estradas tem sua participação aumentada, passando a responder por $25 \%$ da receita total. O somatório das demais receitas passa, então, a representar $75 \%$ da soma total. Em 1840, tal provisionamento em termos nominais era de 290:848\$000 e, em 1850, 
saltou para 364:950\$000, uma elevação de $25 \%$. Ao subtrairmos os provisionamentos com a dívida ativa (12:000\$000), typographia $(150 \$ 000)$ e juros das apólices (10:500\$000), obtemos uma expectativa de arrecadação de 342:300\$000, ou seja, $17 \%$ superior em relação a 1840 .

Direitos de saída e direitos dos animais nos registros do Rio Negro, e agora também Cuarapuava, permaneceram como as principais fontes de receita provincial, representando $63 \%$ do total orçado. No entanto, em 1850 ocorreu uma leve queda na expectativa de arrecadação nos direitos de registros dos animais: o valor foi orçado em 80:000\$000. O mesmo não pode ser afirmado com relação aos direitos de saída: este saltou de 100:000\$000, em 1840, para 150:000\$000 em 1850-um acréscimo de 50\% na comparação entre os dois períodos e uma participação, em 1850, de $41 \%$ diante das receitas.

Tabela 6 -Lei orçamentária de 7850 - Ano financeiro de $7^{\circ}$ de julho de 1850 a 30 de junho de 1857.

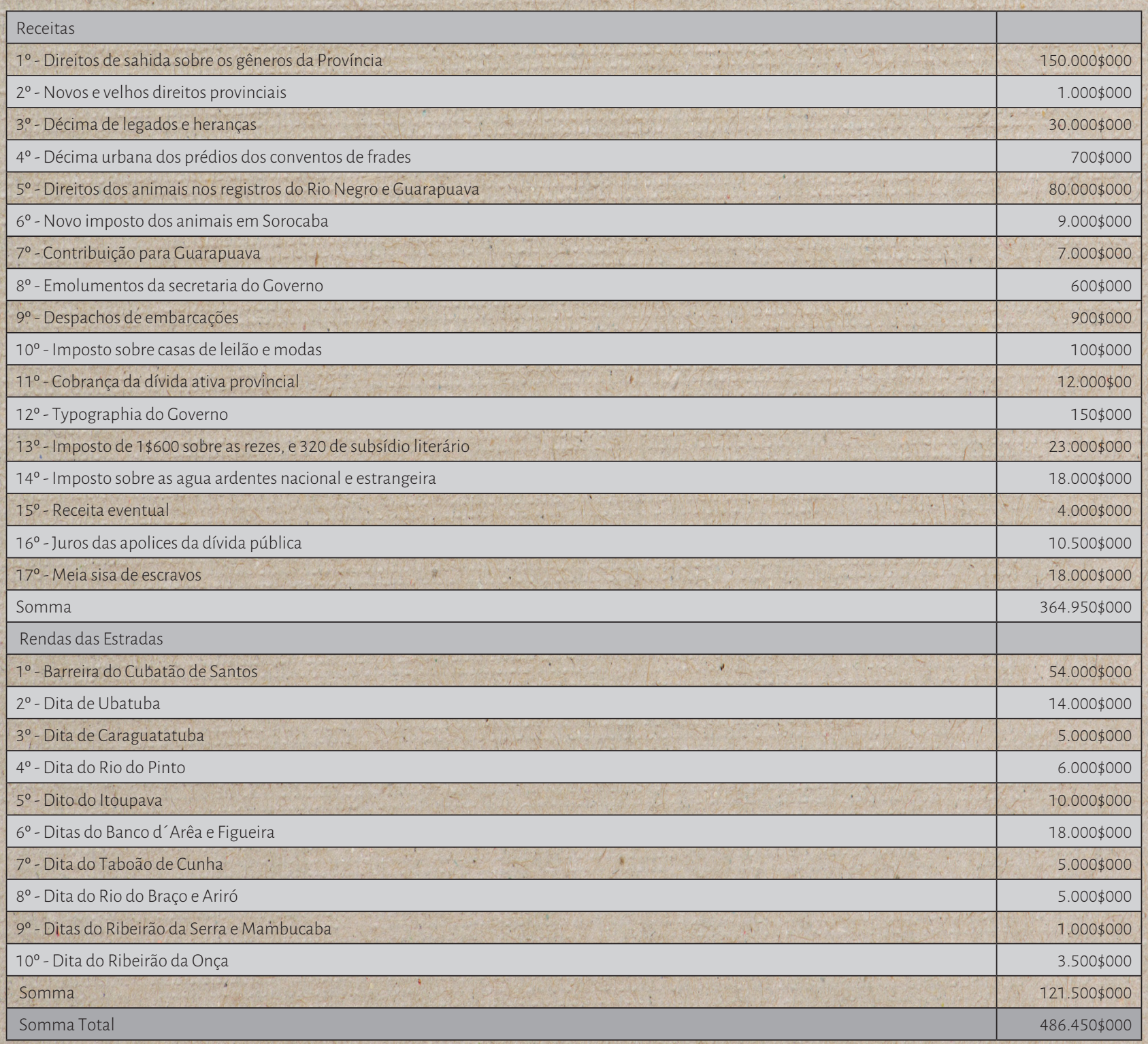

Fonte: Tabela elaborada de acordo com a Lei ${ }^{\circ} 24$, de 02 de julho de 1850 . Província de São Paulo (1850) 
Neste momento, cabe a reflexão acerca dos direitos de saída. No período de 15 anos esse imposto saltou, em termos nominais, de 25:000\$000 para 150:000\$000, uma elevação de 500\%. Em 1835, o mesmo imposto representava $14 \%$ dos provisionamentos em arrecadação. Já no ano de 1850 , os anseios em relação a essa receita representavam $41 \%$ do orçamento. Em síntese, no período de uma década e meia apenas um imposto passou a representar quase a metade do orçamento das receitas (voltando a desconsiderar as rendas das estradas). Não obstante, "a partir de 1846-1847, a exportação do açúcar tende a diminuir e a do café a aumentar. [...]. Depois de 1850-1851, temos uma exportação do café sempre maior que a do açúcar" (PETRONE, 1968, p. 162). Este fato econômico auxilia no entendimento sobre a crescente importância dos direitos de saída para as receitas provinciais.

E mais, considerando outros importantes tributos (a saber: a meia sisa de escravos, os impostos sobre as aguardentes nacionais e estrangeiras, o imposto de $1 \$ 600$ sobre as rezes e 320 de subsídio literário e a décima de legados e heranças), é possível constatar que, embora eles não possuam uma representatividade tão elevada diante da totalidade, houve uma substancial elevação no período de 15 anos. Em valores nominais, a décima sobre legados e heranças aumentou $455 \%$ no período, passando de $5: 400 \$ 000$ em 1835, para 30:000\$000 em 1850. Já o impostosobrea aguardente, que inicialmente era cobrado somente sobre a produção, saltou de 5:400\$000 para 18:000\$000, ou seja, consideráveis $233 \%$. A meia sisa de escravos, cuja arrecadação era estimada em 9:000\$000 em 1835, foi estimada em 18:000\$000 em 1850 , elevação de $100 \%$. Já a expectativa de arrecadação de $1 \$ 600$ sobre as rezes e 320 de subsídio literário partiu de 14:000\$000 em 1835, para 23:000\$000 em 1850, um acréscimo de 64\%.

1. Dessa forma, de acordo com a lei orçamentária de 1850 temos, em grau de relevância:

2. Direitos de saída: $41 \%$ da expectativa de arrecadação;

3. Direitos dos animais nos registros de Rio Negro e Guarapuava: $22 \%$ da expectativa de arrecadação;

4. Décima de legados e heranças: $08 \%$ da expectativa de arrecadação;

5. $1 \$ 600$ sobre as rezes e 320 de subsídio literário: $06 \%$ da expectativa de arrecadação;

6. Imposto sobre a aguardente: $05 \%$ da expectativa de arrecadação;

7. Imposto sobre a meia sisa de escravos: 05\% da expectativa de arrecadação.

Conforme o Cráfico 1, a partir desse orçamento a tendência de elevação na receita orçada - calculada em libras esterlinas - acentua-se. Se nos períodos anteriores, 1835-1840 e 1840-1850, a elevação havia sido de $18,57 \%$ e $23,35 \%$, no período 1850 -1861 ocorre um aumento da ordem de $104,03 \%$. Se analisarmos somente os valores nominais, essa elevação alcança os $130 \%$. E, ainda considerando os valores nominais, por mais que se exclua do orçamento a arrecadação com a dívida ativa, com valor em torno de 126:235\$402, ainda se observa uma elevação de 104\% com relação aos números de 1850. Mais adiante, na análise dos Relatórios de Presidente de Província, será possível discutir as razões para tal incremento. 
Seguindo nossas análises, consideraremos agora a Lei Orçamentária de 1861. Com base na Tabela 7, podemos observar que as rendas das estradas permanecem com a mesmá representatividade que possuíam no orçamento anterior, respondendo por $26 \%$ do total orçado. Quanto às estimativas de receitas, o direito de saída continua sendo a principal fonte de arrecadação, agora representando $48 \%$ das previsões. Contudo, é imprescindível salientar que, se em 1850 esperava-se arrecadar 150:000\$000 com essa fonte de recursos, a lei orçamentária de 1861 prevê uma arrecadação da ordem de 400:000\$000, ou seja, um acréscimo de $167 \%$ com relação ao período anterior, e de $1.500 \%$ se comparado com o valor orçado em 1835 .

Tabela 7 - Lei orçamentária de 1867 - Ano financeiro de $7^{\circ}$ de julho de 7867 a 30 de junho de 1862.

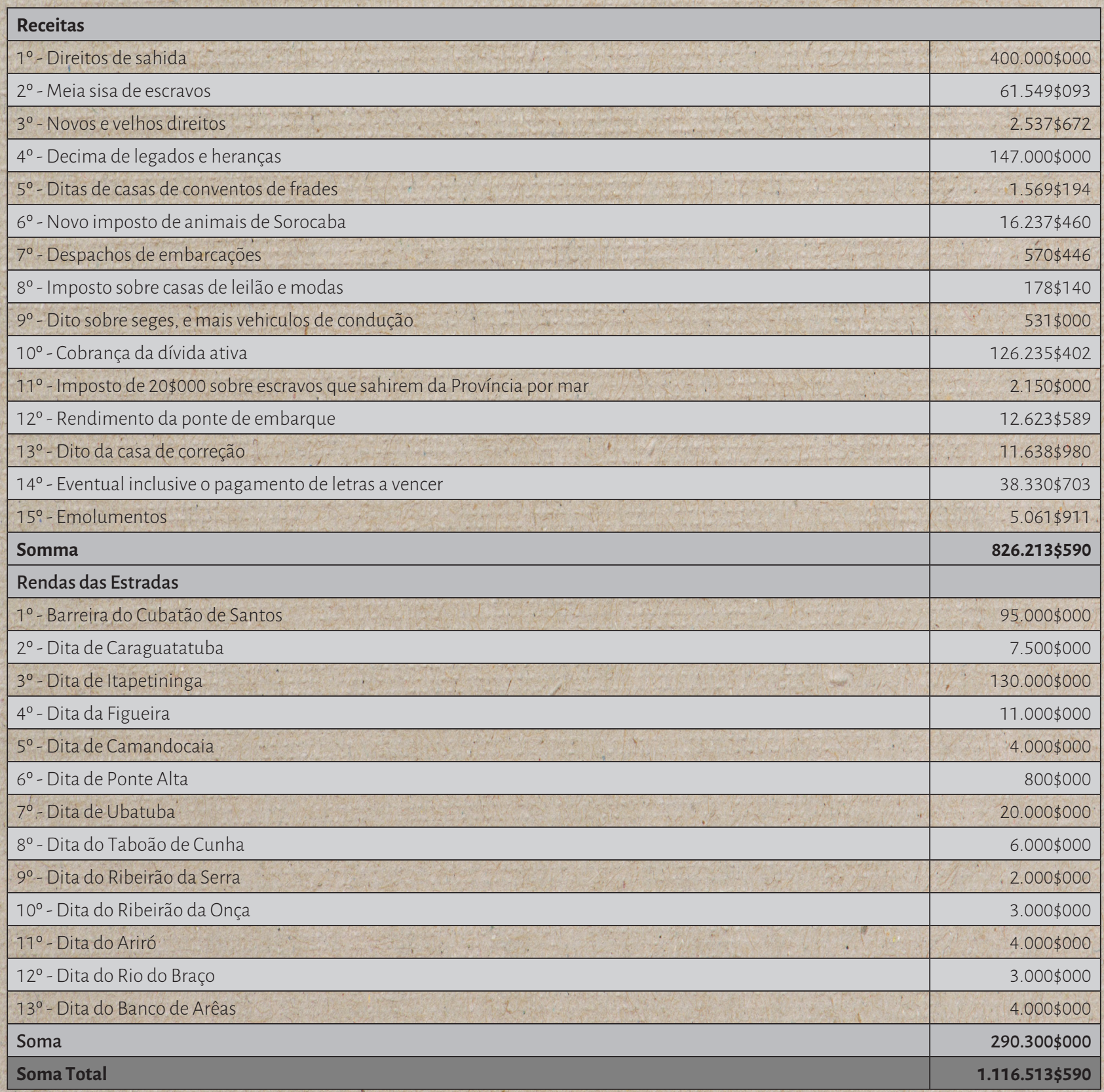

Fonte: Tabela elaborada de acordo com a Lei $n^{\circ} 16$, de 03 de agosto de 1861. Província de São Paulo (1861). 


\section{História Econômicag $\quad$ Dossiê
Demografia Históntá}

Outras duas importantes fontes de renda para a Província são a décima de legados e heranças (147:000\$000) e a meia sisa de escravos (61:549\$093). O somatório desses dois impostos e mais o direito de saída representa $73 \%$ da expectativa de receita. Em 1850 , havia a concentração de $87 \%$ de tal anseio arrecadatório em seis fontes de tributos. No orçamento de 1861, a esperança de arrecadação de $73 \%$ das receitas está concentrada em apenas três tributos.

Ainda que pouco representativos na receita total orçada, é curioso notar a criação de dois tributos que até então não haviam sido mencionados: o imposto sobre seges e demais veículos de condução, pertencente à Receita Ceral e transferido para as Províncias em 1851; e o imposto de $20 \$ 000$ sobre escravos que saíam da província por mar. Criado em 1853, possuía características de imposto de exportação, pois tributavam-se os escravos que eram vendidos para outras Províncias do Império.

Antes de adentrarmos na próxima lei orçamentária, cabe a observação acerca da extinção dos direitos dos animais nos registros do Rio Negro e Guarapuava. Este imposto representou umas das mais importantes fontes de renda da província paulista. Contudo, no ano de 1851 foi transferido para a Província do Paraná, causando um considerável impacto nas finanças de São Paulo.

Retomando a consideração sobre as leis orçamentárias, no orçamento para 1870 é possível observar que, se comparado à Lei Orçamentária de 1861, o valor estimado da receita, em libras esterlinas, deu novo salto, passando de $£ 118.905$ para $£ 224.356$, uma elevação de $88,69 \%$. Todavia, as taxas de barreiras têm sua participação reduzida, respondendo por apenas $15 \%$ da receita total. Tais observações são complementadas pelos dados da Tabela 8.

Tabela 8-Lei orçamentária de 1870 -Ano financeiro de $7^{\circ}$ de julho de 1870 a 30 de junho de 1877.

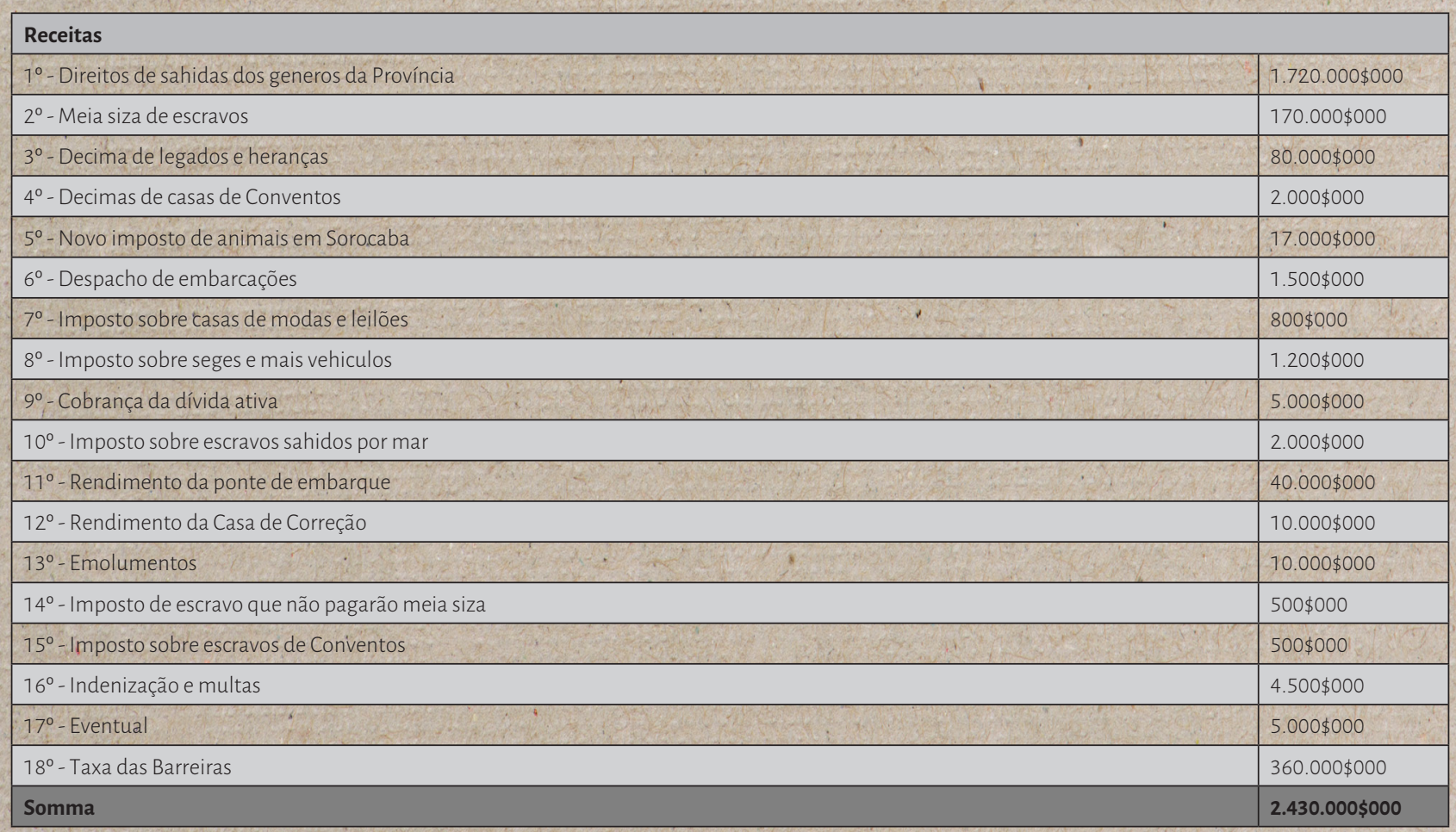

Fonte: Tabela elaborada de acordo com a Lei nº 93, de 21 de abril de 1870. Província de São Paulo (1870). 
Importante mencionar que a principal fonte de renda da Província neste período continua sendo os direitos de saída, assim como constatar que, novamente, a expectativa de arrecadação com tal tributo sofreu forte elevação se comparada à do período anterior. Considerando-se os valores nominais relativos ao orçamento de 1870 , os direitos de saída (1.720:000\$000) representaram consi-' deráveis $83 \%$ da estimativa de receita. Mais uma vez, se compararmos a evolução deste imposto desde o início do período, em 1835, veremos uma elevação de $6.780 \%$ em 35 anos. Se comparado ao valor informado na Lei Orçamentária de 1861, também houve um aumento substancial, na ordem de $330 \%$. A explicação para, em 1870 , os direitos de saída terem representado uma expectativa de arrecadação de $83 \%$ da receita orçada (excluindo-se as barreiras das estradas) é proveniente do bom momento que o café ofereceu aos cofres provinciais paulistas.

Prosseguindo nossa análise e considerando os dados apresentados na Tabela 9, na Lei Orçamentária de 1880 é possível constatar que a receita orçada para aquele ano alcançou o valor de 3.732:371 \$176 réis, uma elevação de $54 \%$ em relação ao orçamento para 1870 . Se considerarmos os valores em libras esterlinas, o aumento alcança porcentagem semelhante, $54,47 \%$.

Tabela 9-Lei orçamentária de 7880 - Ano financeiro de $7^{\circ}$ de julho de 7880 a 30 de junho de 1887.

\begin{tabular}{|c|c|}
\hline \multicolumn{2}{|l|}{ Receitas } \\
\hline $7^{\circ}$ - Direitos de sahida & $1.700: 000 \$ 000$ \\
\hline $2^{\circ}-$ Meia siza de escravos & $200.000 \$ 000$ \\
\hline $3^{\circ}$-Decima de legados e heranças & $\quad 236.082 \$ 537$ \\
\hline $4^{\circ}-$ Decima de uso frutos & $47.216 \$ 500$ \\
\hline $5^{\circ}$ - Decima de casa de Conventos & $3.248 \$ 264$ \\
\hline $6^{\circ}$ - Novo imposto de animais & $5.671 \$ 853$ \\
\hline $7^{0}$ - Despacho de embarcações & $3.853 \$ 050$ \\
\hline $8^{\circ}$ - Rendimento da ponte de embarque & $69.925 \$ 338$ \\
\hline $9^{\circ}-$ Rendimento da penitenciária & $13.611 \$ 248$ \\
\hline $10^{\circ}$-Emolumentos & $20.000 \$ 000$ \\
\hline $11^{\circ}$-Indenizações e multas & $65.161 \$ 944$ \\
\hline $12^{\circ}$ - Eventuais & $5.365 \$ 379$ \\
\hline $13^{\circ}$ - Taxa das Barreiras & $98.609 \$ 000$ \\
\hline $14^{\circ}-$ Imposto de transito & $800.000 \$ 000$ \\
\hline $15^{\circ}$ - Dito adiciónal & $350.000 \$ 000$ \\
\hline $16^{\circ}$ - Dito sobre companhias equestres & $2.080 \$ 000$ \\
\hline $17^{\circ}$ - Dito sobre casas de leilão e modas & $983 \$ 050$ \\
\hline $18^{\circ}$ - Dito sobre seges e outros vehiculos & $3.345 \$ 973$ \\
\hline $19^{\circ}$ - Dito sobre capitalistas & $12.000 \$ 000$ \\
\hline $20^{\circ}$ - Dito sobre loterias & $6.000 \$ 000$ \\
\hline $21^{\circ}$ - Dito predial & $40.000 \$ 000$ \\
\hline $22^{\circ}$ - Cobrança da dívida ativa & $20.000 \$ 000$ \\
\hline $23^{\circ}$-Auxílio do Coverno Geral & $30.000 \$ 000$ \\
\hline Somma & $3.732 .371 \$ 1761^{*}$ \\
\hline
\end{tabular}

*Valor replicado da lei orçamentária, o somatório não é exatamente igual por dificuldade em transcrever o arquivo. Fonte: Tabela elaborada de acordo com a Lei ${ }^{\circ} 156$, de 20 de abril de 1880. Província de São Paulo (1880). 
Pela primeira vez na análise histórica do período em estudo, a expectativa de arrecadação com os direitos de saída não aumentou; ao contrário, houve uma leve queda. Como já referenciado no início do artigo, as exportações foram prejudicadas entre os anos de 1870 e 1871 devido à Guerra Franco-Prussiana, impactando a arrecadação com os direitos de saída. Ademais, no ano financeiro de 1870 os direitos de saída representavam $83 \%$ da expectativa de arrecadação, sendo plausivel que os legisladores tenham efetuado ajustes no decorrer da década a fim de evitar tamanha concentração em uma única fonte de receita.

Ao analisar com mais atenção a Lei Orçamentária de 1880 , observamos a criação de novos tributos, além da elevação da perspectiva de arrecadação em outros já existentes.

Dentre essas novidades, destacamos o Imposto de Trânsito, criado em 1872, com uma estimativa de arrecadação de 800:000\$000 réis em 1880. Este imposto ganhou importância nas receitas públicas por ter como base de incidência o transporte de mercadorias através das malhas ferroviárias e a
As barreiras de estradas vão perdendo a importância que possuíam para as finanças públicas por conta da queda no trânsito de pessoas, muares e mercadorias através das estradas. Tal queda é explicada pela ascensão que as ferrovias passam a adquirir nos caminhos de São Paulo. Além disso, não podemos deixar de destacar a relevância que as estradas de ferro possuem para o escoamento do café até os portos, facilitando o transporte e a comercialização deste produto de destaque na pauta de exportações paulista. compra de passagens. Desta forma, é possível verificar a transformação econômico-social ocorrida na província no tocante aos meios de locomoção. As barreiras de estradas vão perdendo a importância que possuíam para as finanças públicas por conta da queda no trânsito de pessoas, muares e mercadorias através das estradas. Tal queda é explicada pela ascensão que as ferrovias passam a adquirir nos caminhos de São Paulo. Além disso, não podemos deixar de destacar a relevância que as estradas de ferro possuem para o escoamento do café até os portos, facilitando o transporte e a comercialização deste produto de destaque na pauta de exportações paulista.

Na sequência, é possível constatar o Imposto Adicional, orçado em 350:000\$.000 réis. O imposto adicional foi criado em 1865 e extinto em 1866, reaparecendo em 1877 e permanecendo até 1891.

Em sua primeira referência, em 1865 , era de $2 \%$ sobre a totalidade líquida das heranças sem testamento, heranças testamentárias, legados e doações "causa mortis". Em 1877, passou a recair no valor dos impostos e taxas cobrados sobre todos os objetos tributados que não fossem 
expressamente isentados em lei, numa proporção de $20 \%$. A lei n ${ }^{\circ} 86-\mathrm{A}$, de 25 de junho de 1881 , manteve essa taxa de $20 \%$, reduzindo, porém, a $10 \%$ aquela sobre os direitos de saída do café. (TESSITORE, 1995, p. 168).

O somatório destes dois tributos alcança 1.150:000\$000 réis, perfazendo $32 \%$ do total da receita orçada.

E mais, ainda que representem valores menores, há que se mencionar a criação de alguns novos tributos e rendimentos, tais como: Décima de usufrutos; Rendimento da Penitenciária; Imposto sobre companhias equestres; Imposto sobre capitalistas; Imposto sobre loterias; Imposto Predial; além do Auxílio do Coverno Geral. Estes impostos demonstram que, mesmo timidamente, as atividades econômicas, sociais e urbanas passam a adquirir certa relevância na arrecadação pública. É possível observar o início de um movimento que vai ganhando importância no desenvolvimento econômico paulista: o dinamismo dos centros urbanos da província.

E por fim, chegamos ao estudo do último orçamento do período. Com base nas informações apresentadas na Tabela 10, observamos que, se comparada à lei orçamentária anterior, houve um reajuste, em valores nominais, da receita orçada da ordem de quase $36 \%$.

Se considerados os valores em libras esterlinas, essa porcentagem alcança os $60,93 \%$. A razão para esse discrepante comportamento reside na valorização cambial sofrida pelo mil-réis frente à libra esterlina durante a década de 1880 , sendo objetivo do Império a volta da paridade ideal estabelecida por lei no final da década de 1840, equivalente a uma taxa de câmbio de 26 pence/por mil-réis.

Em relação aos anos anteriores, as taxas das barreiras perdem de forma significativa sua expressividade, correspondendo, na Lei Orçamentária de 1880, a aproximadamente $1 \%$ da receita orçada. E mais, as principais fontes de arrecadação estão agora concentradas em cinco tributos:

1. Direitos de saída: $45 \%$ da estimativa de arrecadação;

2. Imposto de transporte ou de trânsito: $26 \%$ da estimativa de arrecadação;

3. Taxa Adicional: $08 \%$ da estimativa de arrecadação;

4. Imposto Predial: $07 \%$ da estimativa de arrecadação;

5. Décima de Legados e Heranças: $04 \%$ da estimativa de arrecadação. 


\section{História Econômicag $\quad$ Dossiê
Demografia Histónica}

Tabela 10-Lei orçamentária de 1889 -Ano financeiro de $7^{\circ}$ de julho de 1889 a 30 de junho de 1890.

\begin{tabular}{|c|c|}
\hline Receitas & \\
\hline $7^{0}-$ Direitos de sahida & $2.300 .000 \$ 000$ \\
\hline $2^{\circ}$ - Taxa da ponte de embarque em Santos & $108.300 \$ 000$ \\
\hline $3^{\circ}$ - Despacho de embarcações & $13.200 \$ 000$ \\
\hline $4^{\circ}$ - Decima de legados e heranças & $215.750 \$ 000$ \\
\hline $5^{\circ}$ - Decima de uso-fruto & $15.000 \$ 000$ \\
\hline $6^{\circ}$ - Imposto de animais em Itarare e Sorocaba & $31.280 \$ 000$ \\
\hline $7^{0}-$ Taxa das barreiras & $1=16.000 \$ 000$ \\
\hline $8^{\circ}$ - Imposto de transporte ou de transito & $1.300 .000 \$ 000$ \\
\hline $9^{\circ}$ - Dito sobre casas de leilão & $3: 220 \$ 000$ \\
\hline $10^{\circ}$ - Dito sobre casas de modas & $1.600 \$ 000$ \\
\hline $17^{\circ}$ - Dito sobre seges e outros vehiculos & $4.570 \$ 000$ \\
\hline $12^{\circ}$ - Dito sobre capitalistas & $15.000 \$ 000$ \\
\hline $13^{\circ}$ - Dito sobre vendedores de bilhetes de loterias estranhas às da Província . & $5.200 \$ 000$ \\
\hline $14^{\circ}$ - Dito Predial & $350.000 \$ 000$ \\
\hline $15^{\circ}$ - Dito sobre companhias equestres & $6.000 \$ 000$ \\
\hline $16^{\circ}$ - Emolumentos & $16.200 \$ 000$ \\
\hline $17^{\circ}$ - Novos direitos por diversas mercês & $=19.000 \$ 000$ \\
\hline $18^{\circ}$ - Cobrança da dívida ativa & $70.000 \$ 000$ \\
\hline $19^{\circ}-$ Taxa adicional & $400.000 \$ 000$ \\
\hline $20^{\circ}$ - Indenizações & $58.200 \$ 000$ \\
\hline $21^{\circ}$ - Receita eventual, compreendendo as multas por infração de lei ou regulamento, e os dividendos das ações da companhia Ituana & $101.200 \$ 000$ \\
\hline \multicolumn{2}{|l|}{$22^{\circ}$ - Selo das patentes de oficiais da guarda nacional, arrecadado pela Fazenda Ceral } \\
\hline $23^{\circ}$ - Rendimento dos estabelecimentos provinciais & $11.400 \$ 000$ \\
\hline Somma & $5.061 .120 \$ 000$ \\
\hline
\end{tabular}

Fonte: Tabela elaborada de acordo com a Lei n ${ }^{107}$, de 09 de abril de 1889. Província de São Paulo (1889).

Outro ponto importante a ser ressaltado é a elevação na participação relativa dos direitos de saída no cômputo da receita orçada. Conforme mostra a Tabela 11, no início do período estudado, especificamente na primeira lei orçamentária considerada, os direitos de saída respondiam por $14 \%$ do total orçado (desconsiderando as barreiras). Essa porcentagem apresenta uma clara tendência de crescimento, chegando a responder por $83 \%$ do total orçado no ano de 1870 .

Tabela 11 - Participação dos direitos de saída na receita orçada. São Paulo, 1835-1889

\begin{tabular}{lc}
\hline Ano & Participação na receita orçada \\
\hline 1835 & $14 \%$ \\
1840 & $35 \%$ \\
1850 & $41 \%$ \\
1861 & $48 \%$ \\
1870 & $83 \%$ \\
1880 & $46 \%$ \\
1889 & $45 \%$ \\
\hline
\end{tabular}

Fonte: Leis orçamentárias paulistas. 
Dessa forma, analisamos a evolução das leis orçamentárias provinciais paulistas ao longo do período 1835-1889. A seguir, a fim de complementar as análises, serão considerados os Relatórios de Presidente de Província.

\section{O que dizem os Relatórios de Presidente de Província}

Os relatórios elaborados pelo Presidente de Província no início de cada ano representam importante fonte de estudos para a compreensão das finanças da Província, pois é através de tais documentos

Pormeio das alterações das bases de incidência, e crescimento ou queda da representatividade que cada tributo passa a ter no decorrer do século XIX, é possível observar o dinamismo pelo qual passou a economia paulista no período imperial. Em suma, as transformações econômicas e sociais ocorridas na Província são claramente exemplificadas nas formas de arrecadação tributária. quese torna possível averiguarse as receitas orçadas eram de fato arrecadadas, bem como constatar se tais receitas eram suficientes ou não para cobrir os gastos necessários.

Em linhas gerais, é possível afirmar que raramente o orçamento correspondia exatamente ao realizado; em alguns momentos a receita orçada era superior à realizada e, em outros momentos, era inferior. A mesma conclusão pode ser feita com relação às despesas.

Contudo, antes de entrarmos na análise do conteúdo específico dos relatórios, se faz necessária, ainda que de maneira breve, a análise do contexto econômico e social da Província de São Paulo nesse momento, retomando a discussão sobre o desenvolvimento paulista na primeira metade do séculoXIX.

Por meio das alterações das bases de incidência, e crescimento ou queda da representatividade que cada tributo passa a ter no decorrer do século XIX, é possível observar o dinamismo pelo qual passou a economia paulista no período imperial. Em suma, as transformações econômicas e sociais ocorridas na Província são claramente exemplificadas nas formas de arrecadação tributária.

Dessa forma, por meio das leis orçamentárias torna-se possível verificar que, se no início as rendas das estradas/taxa das barreiras estavam entre as mais vultosas fontes de expectativa de arrecadação para os cofres públicos paulistas, no final do período, com o desenvolvimento das estradas de ferro, sua participação torna-se bem menos representativa.

A importância inicial dessa tributação reside, em boa medida, no fato de as estradas paulistas representarem, desde meados do século XVII, um importante caminho de passagens de muares e carros de boi carregados de mercadorias, bem como comerciantes que transitavam entre tais caminhos. São Paulo possuía uma localização privilegiada no sentido de simbolizar um ponto 
de ligação entre o norte e o sul do país, assim como passagem obrigatória para aqueles que necessitassem se locomover à região das Minas Cerais através do "caminho velho". Ademais, internamente tais estradas também possuíam expressiva importância no tocante à locomoção da produção açucareira paulista e seu escoamento através dos portos.

Com o decorrer das décadas e o advento das estradas de ferro, as taxas de barreira foram perdendo representatividade dentre as fontes arrecadatórias. Na Lei Orçamentária de 1889, as rendas das estradas perfaziam aproximadamente $1 \%$ da estimativa de receita. A queda tão abrupta desse tributo no orçamento pode ser explicada pela pouca relevância, como foi mencionado anteriormente, que os caminhos das estradas passaram a ter com o advento das ferrovias. Sendo assim, como reflexo podemos observar a criação, em 1872, do imposto de trânsito, cuja base de incidência era o "despacho dos gêneros e da venda das passagens nas Estradas de Ferro, antes do embarque" (TESSITORE, 1995, p. 231). Na Lei Orçamentária de 1880, a expectativa de arrecadação com o imposto de trânsito representou aproximadamente $26 \%$ da renda orçada. Desta forma, verifica-se o importante papel que as estradas de ferro vão adquirindo na economia paulista, não só como meio de transporte, mas também como fonte de arrecadação.

Outro ponto que merece destaque na evolução acompanhada é o aumento da importância dos direitos de saída para a arrecadação pública provincial. Por meio das leis orçamentárias analisadas, foi possível observar que 0 antigo dízimo possuía uma representatividade calculada no orçamento de 1835 de $14 \%$, passando a representar, no orçamento de $1889,45 \%$.

Em média, calculou-se que os direitos de saída representavam $44,5 \%$ das receitas orçadas ao longo de todo o período. Esta tendência crescente está intimamente relacionada com a expansão cafeeira na economia paulista e o papel de destaque que este produto passou a adquirir nas exportações da província a partir de meados de 1850. Todavia, faz-se importante esclarecer que os direitos de saída também incidiam sobre o açúcar e demais 'gêneros agrícolas e manufaturados. No entanto, foi a exportação do café que favoreceu o crescimento arrecadatório deste tributo.

Voltando aos relatórios, notamos que seus conteúdos, em alguns anos, enaltecem e comemoram o fato de a Província de São Paulo encerrar o ano fiscal com superávit. Contudo, tantos outros lamentam a situação calamitosa na qual as finanças se encontram, não sendo a receita arrecadada capaz de sanar todos os gastos que se fizeram necessários.

Havia também, como há de se constatar, a dificuldade em arrecadar oș impostos devidos: “É cada vez maior o extravio do imposto da meia siza da venda de escravos, pois que a administração não tem um meio direto nem indireto de obstar a defraudação que dele se faz, na maior parte da Província. Hoje só paga este imposto quem quer [...]." (ALVIM, 1842, p. 20).

Ainda.no relatório do ano de 1842, o Presidente de Província relata a importância de se criar no- 
vas formas de tributos diante das dificuldades em se arrecadar al gumas receitas orçadas por conta de fatores exógenos à capacidade de se efetuar a referida cobrança:

[...] a falta que necessariamente vão sentir os cofres provinciais pela infalível diminuição da venda proveniente do imposto do Rio Negro [...], cumpre portanto que se trate, quanto antes, de criar uma renda que se possa, se não substituir ao menos diminuir alguma coisa a falta que aquela há de fazer [...]. Considerações muito poderosas obrigarão o Governo Imperial a mandar interceptar o comércio com a Província do Rio Grande do Sul. (ALVIM, 1842, p. 21).

Diante do exposto, o então Presidente de Província apela aos parlamentares "que se adotem as medidas que vossa sabedoria e patriotismo vos indicar melhor, pois de acordo com o orçamento haverá déficit". (ALVIM, 1842, p. 22).

Tantos outros Presidentes, em anos subsequentes, relatam das necessidades de rendas extras a serem destinadas aos consertos de pontes e estragos com as chuvas, por exemplo, bem como da dificuldade em se cobrar a dívida ativa provincial. Tratam, ainda, dos conflitos existentes entre Municípios e Província, ao afirmar que "as localidades querem tudo, mas não querem contribuir para nada". (MOTA, 1851, p. 10).

Contudo, é o Relatório de Presidente de Província do ano de 1852 que traz maior clareza acerca das receitas e despesas orçadas e realizadas, cujas informações aparecem sumarizadas no Quadro 1.

Quadro 1-Resumo da Receita e Despesa comum da Província. São Paulo, 1848-1852.

\begin{tabular}{|c|c|c|}
\hline \multicolumn{3}{|c|}{1848 a 1849} \\
\hline & Receita & Despesa \\
\hline Orçada & $386: 160 \$ 000$ & $429: 586 \$ 000$ \\
\hline Efetiva & $376: 615 \$ 000$ & $333: 640 \$ 000$ \\
\hline \multicolumn{3}{|c|}{1849 a 1850} \\
\hline 48 & Receita & Despesa \\
\hline Orçada & $290: 150 \$ 000$ & $365: 783 \$ 000$ \\
\hline Efetiva & $227: 425 \$ 000$ & $344: 516 \$ 000$ \\
\hline \multicolumn{3}{|c|}{1850 a 1851} \\
\hline & Receita & Despesa \\
\hline Orçada & $364: 950 \$ 000$ & $428: 356 \$ 000$ \\
\hline Efetiva & $378: 621 \$ 000$ & $390: 434 \$ 000$ \\
\hline \multicolumn{3}{|c|}{1851 a 1852} \\
\hline & Receita & Despesa \\
\hline Orçada & $285: 550 \$ 000$ & $337: 937 \$ 000$ \\
\hline Efetiva & $170: 837 \$ 680^{\prime}$ & $146: 365 \$ 000$ \\
\hline
\end{tabular}

Fonte: Quadro elaborado de acordo com informações disponíveis em Araujo (1852, p. 71). ${ }^{17}$

Infelizmente, os demais relatórios não apresentam essa riqueza de detalhes, todavia, através dessas informações torna-se possível averiguar que raramente os valores orçados eram con-

17 Os valores apresentados não levam em consideração as receitas e despesas das Barreiras orçadas e realizadas. 


\section{História Econômicag Dossiê}

cretizados. Também é possível constatar que mesmo sendo a arrecadação efetiva, em alguns casos, superior à orçada, ainda assim as finanças provinciais apresentavam déficit, como relata o Presidente de Província:

Há de haver um déficit e já o havia em anos anteriores, como consta das leis respectivas, cuja despesa orçada é maior que a receita orçada [...]. O remédio me parece que não pode ser outro senão, como a Tesouraria indica, restabelecer a receita pública como era antes: é danoso e impopular criar ou elevar impostos sem necessidade averiguada e evidente, mas é também temeridade abolir ou reduzir impostos a que o povo já está habituado, que são absolutamente indispensáveis, dos quais não se pode prescindir sem menoscabo das necessidades públicas, sem embaraço da administração [...]. (ARAUjO, 1852, p. 73).

O relatório de Presidente de Província do ano de 1860 também se preocupa em retratar o déficit do ano de 1858 a 1859, cita o mau estado das finanças, a necessidade em se arrecadar quantias que estavam em poder de alguns coletores, bem como a urgência na criação de novos impostos. O resultado já foi apresentado acima: a elevação de quase $130 \%$, em termos nominais, da receita orçada entre as Leis Orçamentárias de 1850 e 1861.

Relatórios dos anos seguintes apresentam poucas alterações com relação aos informes relatados, ora reclamando dos déficits e defendendo a necessidade da criação de novos tributos, ora comemorando o estado lisonjeiro das finanças provinciais. Contudo, são esses relatórios que trazem esclarecimentos acerca da realidade enfrentada pela Província, sobretudo no que se refere à discrepância existente entre valores orçados e efetivamente arrecadados.

Através da análise das leis orçamentárias foi possível constatar que a evolução do provisionamento da receita sofreu uma elevação na ordem de aproximadamente $1.300 \%$ entre 1835 e 1889, havendo, em alguns anos dentre os períodos estudados, crescimentos consideráveis. Tais valores, já mencionados anteriormente, encontram-se reproduzidos a seguir, na Tabela 12.

Tabela 12 - Evolução da receita provincial. São Paulo, anos selecionados.

\begin{tabular}{|c|c|c|c|}
\hline \multirow{2}{*}{ Ano } & Receita Orçada & Receita Orçada & Variação \% em relação ao período anterior \\
\cline { 2 - 4 } & (valores nominais) & (valores em libras esterlinas) & (em libras esterlinas) \\
\hline 1835 & 243.700 .000 & 39.846 & $18,57 \%$ \\
\hline 1840 & 365.684 .000 & 47.246 & $23,35 \%$ \\
\hline 1850 & 486.450 .000 & 58.278 & $104,03 \%$ \\
\hline 1861 & 1.176 .513 .590 & 118.905 & $88,69 \%$ \\
\hline 1870 & 2.430 .000 .000 & 224.356 & $54,47 \%$ \\
\hline 1880 & 3.732 .371 .176 & 346.553 & $60,93 \%$ \\
\hline 1889 & 5.061 .120 .000 & 557.699 & \\
\hline
\end{tabular}

Fonte: Leis orçamentárias paulistas. 
Entretanto, com o objetivo de analisar como se deu a evolução per capita da carga tributária orçada (em libras esterlinas) na Província paulista, coletamos al guns dados relativos à população livre de São Paulo. Dessa forma, foi elaborada a Tabela 13, cujo conteúdo nos permite concluir que a tributação per capita da província dobrou entre o início e o final do período estudado, passando de uma razão de $20 \%$ de uma libra esterlina, para $40 \%$. Importante ressaltar que o relevante crescimento populacional observado no período se deveu, sobretudo, à imigração promovida e em muitos momentos financiada pela atividade cafeeira. Tal fluxo populacional iniciou-se timidamente na década de 1850 , com o fim do tráfico negreiro, tomando maior volume a partir da década de 1870 , em especial após a Lei do Ventre Livre.

Tabela 13 - Carga Tributária Per Capita (libras esterlinas). São Paulo, 1835-188918

\begin{tabular}{|c|c|c|c|c|}
\hline Ano & $\begin{array}{c}\text { Receita Orçada } \\
\text { (valores em libras esterlinas) }\end{array}$ & População Livre & $\begin{array}{c}\text { Carga Tributária } \\
\text { Per Capita (\%) }\end{array}$ & Variação (\%) entre os Períodos \\
\hline 1836 & 39.218 & 200.129 & 0,20 & $5 \%$ \\
\hline 1854 & 63.029 & 301.541 & 0,21 & $4,76 \%$ \\
\hline 1871 & 150.150 & 680.742 & 0,22 & $59,09 \%$ \\
\hline 1887 & 384.490 & 1.102 .467 & 0,35 & $14,29 \%$ \\
\hline 1889 & 557.514 & 1.384 .753 & 0,40 & \\
\hline
\end{tabular}

Fonte: Leis orçamentárias paulistas e Bassanezi (1998).

Ou seja, o café foi o grande responsável tanto pelo crescimento da arrecadação paulista no período, por meio do recebimento dos chamados direitos de saída, como por incentivar o crescimento populacional, principalmente por meio da imigração, e até mesmo por promover modificações na infraestrutura de transportes da Província e fomentar seu mercado interno.

\section{Considerações finais}

Com base nas informações levantadas e nas análises desenvolvidas, foi possível constatar que a Província de São Paulo, no período entre os anos de 1835 e 1889, passou por importantes transformações sob o ponto de vista tributário, transformações estas provenientes da profunda modificação econômica e social verificadas na Província durante todo o período imperial.

18 Elaboração própria de acordo com dados coletados nas Leis Orçamentárias paulistas e "Estatísticas Históricas São Paulo do Passado/Dados Demográficos, 1836-1920", (BASSANEZI, 1998). O cruzamento de dados entre as duas fontes trata-se de uma estimativa, pois o ano financeiro ia de $1^{\circ}$ de julho do ano em questão a 30 de junho do ano subsequente. A única exceção é para o ano de 1887, quando foram utilizados os dados da lei orçamentária do ano financeiro de $7^{\circ}$ de julho de 1887 a 30 de junho de 1888 e os dados da população de 1886 . Tal metodologia foi necessária por não haver disponibilidade de informações populacionais para o ano de 1887, muito menos os valores da receita orçada para o ano de 1886. Levou-se em consideração somente a população livre, não havendo neste caso a distinção entre sexo e idade. 
Alguns impostos existentes nas primeiras leis orçamentárias, como direitos dos animais nos registros do Rio Novo, deixaram de incidir has últimas leis orçamentárias, devido ao fato de serem transferidos para a Província do Paraná em 1851. Interessante notar que na primeira Lei Orçamentária, de 1835, tal tributo era o mais representativo na base de arrecadação. Já outros tributos relacionados nas últimas leis orçamentárias foram criados no decorrer das décadas, não havendo nenhuma menção a eles no período inicial, como é o caso do imposto de transporte ou de trânsito, cuja cobrança recaía no transporte de mercadorias sobre as maIhas ferroviárias e compras de passagens, segunda arrecadação mais expressiva da Lei Orçamentária de 1889.

Contudo, constatação interessante a ser feita refere-se ao comportamento da rubrica direitos de saída no decorrer do período. Na Lei Orçamentária de 1835, o dito tributo representava somente $14 \%$ da expectativa de arrecadação da Província. Já na Lei Orçamentária de 1870 , essa única fonte de arrecadação alcançou consideráveis $83 \%$ de representatividade, sendo calculada sua participação média na receita orçada da Província em 44,5\%. Em boa medida, esse crescimento reflete a importância crescente da economia cafeeira no território paulista. Não obstante, por mais que novos tributos fossem criados e que outros fossem extintos no decorrer do período imperial, desde 1840 os tais direitos de saída tornaram-se a principal fonte da renda provincial. E mais, sempre que geadas ou outras intempéries comprometessem as lavouras de café ou de açúcar - os produtos exportados de maior valor para a província -, ou que fatores externos à Província e até mesmo ao país interferissem no cenário político, tais como guerras ou crises econômicas, principalmente na Europa ou nos Estados Unidos, nossos principais compradores, a arrecadação dos direitos de saída èra impactada, prejudicando assim as finanças provinciais.

A narrativa de tais dificuldades é corroborada pelos Relatórios elaborados pelos Presidentes de Província, importante registro documental que nos possibilita compreender um pouco da dinâmica e do cotidiano da Província de São Paulo no período imperial, dinâmica essa ressaltada aqui sob a ótica das finanças públicas.

Ademais, com base nas análises efetuadas, foi possivel concluir que, infelizmente, quase nada mudou em relação ao Brasil dos períodos colonial e imperial, no qual sempre que os cofres públicos passavam por dificuldades, a saída encontrada e mais rapidamente implementada era o aumento da carga tributária. 


\section{Referências}

\section{Fontes primárias consultadas:}

ACUIAR, Raphael Tobias de. Discurso Recitado pelo Ex. ${ }^{\text {mo }}$ Presidente Raphael Tobias de Aguiar por Ocasião da Abertura da Assembleia Legislativa da Província de São Paulo. São Paulo: Typographia de Costa Silveira, 1841. Disponível em: <http://brazil.crl.edu/bsd/bsd/u1083/000001.html>. Acesso em: 26 nov. 2016

ALVIM, Miguel de Souza Mello e. Discurso Recitado pelo Ex. ${ }^{\text {mo }}$ Presidente Miguel de Souza Mello e Alvim por Ocasião da Abertura da Assembleia Legislativa da Província de São Paulo. São Paulo: Typographia Imparcial de Silva Sobral, 1842. Disponível em: <http://brazil.crl.edu/bsd/bsd/976/000001.html>. Acesso em: 26 nov. 2016.

ARAUJO, José Thomaz Nabuco D. Discurso com que o llustríssimo e Excelentíssimo Conselheiro Dr. José Thomaz Nabuco D Araujo, Presidente da Província de São Paulo, abriu a Assembleia Legislativa Provincial. São Paulo: Typographia do Governo, 1852. Disponível em: <http://brazil.crl.edu/bsd/bsd/986/000002.html>. Acesso em: 26 nov. 2016.

AZEVEDO, Pedro Vicente de. Relatório apresentado à Assembleia Legislativa Provincial de São Paulo pelo Presidente da Província, Dr. Pedro Vicente de Azevedo. São Paulo: Typographia à vapor de Jorge Seckler \& Comp., 1889. Disponível em: <http://brazil.crl.edu/bsd/bsd/1033/000002.html>. Acesso em: 27 nov. 2016.

BARROS, Prudente ], de Moraes. Exposição apresentada ao Dr. Jorge Tibiriça pelo Dr Prudente ], de Moraes Barros, $7^{\circ}$ Covernador do Estado de São Paulo. São Paulo: Typ. Vanordex \& Comp,1890. Disponível em: <http://brazil.crl.edu/bsd/bsd/u1145/000002.html>. Acesso em: 27 nov. 2016.

BRITO, Laurindo Abelardo de. Relatório apresentado à Assembleia Legislativa Provincial de S. Paulo pelo Presidente da Província, Laurindo Abelardo de Brito. Santos: Typ. à vapor do Diario de Santos, 1880. Disponível em: <http://brazil.crl.edu/bsd/bsd/1024/000002.html>. Acesso em: 26 nov. 2016.

BRITO, Laurindo Abelardo de. Relatório apresentado à Assembleia Legislativa Provincial de S. Paulo pelo Presidente da Província, Laurindo Abelardo de Brito. Santos: Typ. à vapor do Diario de Santos, 1881. Disponível em: <http://brazil.crl.edu/bsd/bsd/1025/000002.html>. Acesso em: 26 nov. 2016.

HENRIQUES, Antonio José. Discurso com que o llustríssimo e Excelentíssimo Senhor Conselheiro Antonio José Henriques, Presidente da Província de São Paulo, abriu a Assembleia Legislativa Provincial. São Paulo: Typographia Imparcial de Joaquim Roberto de Azevedo Marques, 1861. Disponível em: <http://brazil.crl. edu/bsd/bsd/998/000002.html>. Acesso em: 26 nov. 2016 .

MENDONÇA, João Jacyntho de. Relatório apresentado à Assembleia Legislativa da Província de São Paulo na 1.a Sessão da 14.a Legislatura pelo Presidente, Doutor]oão Jacyntho de Mendonça. São Paulo: Typ. Imparcial de Joaquim Roberto de Azevedo Marques, 1862. Disponível em: $<$ http://brazil.crl.edu/bsd/bsd/999/000002. html>. Acesso em: 26 nov. 2016. 


\section{História Econômicag $\quad$ Dossiê
Demografia Históncá}

MOTA, Vicente Pires da. Discurso com que o llustríssimo e Excelentíssimo Doutor Vicente Pires da Mota, Presidente da Província de São Paulo, abriu a Assembleia Legislativa Provincial. São Paulo: Typographia do Coverno, 1850. Disponível em: <http://brazil.crl.edu/bsd/bsd/984/000002.html>. Acesso em: 26 nov. 2016.

MOTA, Vicente Pires da. Discurso com que o.llustríssimo e Excelentíssimo Conselheiro Doutor Vicente Pires da Mota, Presidente da Província de São Paulo, abriu a Assembleia Legislativa Provincial. São Paulo: Typographia do Governo, 1851. Disponível em: <http://brazil.crl.edu/bsd/bsd/985/000002.html>. Acesso em: 26 nov. 2016.

PROVÍNCIA DE SÃO PAULO. Lei n 17, de 11 de abril de 1835. [Lei orçamentária da Província de São Paulo, 1835]. Assembleia Legislativa do Estado de São Paulo [Repositório legal]. Disponível em: <https://www.al.sp.gov. br/norma/138215>. Acesso em: 24 nov. 2016.

PROVÍNCIA DE SÃO PAULO. Lei n 40, de 18 de março de 1836. [Lei orçamentária da Província de São Paulo, 1836]. Assembleia Legislativa do Estado de São Paulo [Repositório legal]. Disponível em: <http://www.al.sp.gov. br/repositorioAH/Acervo/Alesp/Imperio/Falp_539/PR36_041.pdf>. Acesso em: 14 ago. 2017.

PROVÍNCIA DE SÃO PAULO. Lei n ${ }^{\circ} 11$, de 23 de março de 1839. [Lei orçamentária da Província de São Paulo, 1839]. Assembleia Legislativa do Estado de São Paulo [Repositório legal]. Disponível em: <http://www.al.sp.gov. br/repositorioAH/Acervo/Alesp/Imperio/Falp 543/PR39 037.pdf>. Acesso em: 14 ago. 2017.

PROVÍNCIA DE SÃO PAULO. Lei ${ }^{\circ}$ 17, de 26 de março de 1840. [Lei orçamentária da Província de São Paulo, 1840]. Assembleia Legislativa do Estado de São Paulo [Repositório legal]. Disponível em: <https://www.al.sp.gov. br/norma/139528>. Acesso em: 24 nov. 2016.

PROVÍNCIA DE SÃO PAULO. Lei nº 40, de 23 de março de 1844. [Lei orçamentária da Província de São Paulo, 1844]. Assembleia Legislativa do Estado de São Paulo [Repositório legal]. Disponível em: <http://www.al.sp.gov. br/repositorioAH/Acervo/Alesp/Imperio/Falp_547/PR44_025.pdf>. Acesso em: 14 ago. 2017.

PROVÍNCIA DESÃO PAULO. Lei n ${ }^{0}$ 10, de 19 de fevereiro de 1845. [Lei orçamentária da Província de São Paulo, 1845]. Assembleia Legislativa do Estado de São Paulo [Repositório legal]. Disponível em: <http://www.al.sp. gov.br/repositorioAH/Acervo/Alesp/Imperio/Falp_548/PR45_001.pdf>. Acesso em: 14 ago. 2017.

PROVÍNCIA DE SÃO PAULO. Lei ${ }^{\circ}$ 24, de 02 de julho de 1850. [Lei orçamentária da Província de São Paul, 1850]. Assembleia Legislativa do Estado de São Paulo [Repositório legal]. Disponível em: <https://www.al.sp.gov. br/norma/139770 >. Acesso em: 24 nov. 2016.

PROVÍNCIA DE SÃO PAULO. Lei n 18, de 02 de maio de 1853. [Lei orçamentária da Província de São Paulo, 1853]. Assembleia Legislativa do Estado de São Paulo [Repositório legal]. Disponível em: <http://www.al.sp.gov. br/repositorioAH/Acervo/Alesp/Imperio/Falp_555/PR53_016.pdf>. Acesso em: 14 ago. 2017.

PROVÍNCIA DE SÃO PAULO. Lei n 30, de 10 de maio de 1854. [Lei orçamentária da Província de São Paulo, 1854]. Assembleia Legislativa do Estado de São Paulo [Repositório legal]. Disponível em: <http://www.al.sp.gov. br/repositorioAH/Acervo/Alesp/Imperio/Falp 555/PR54 011.pdf>. Acesso em: 14 ago. 2017.

PROVÍNCIA DE SÃO PAULO. Lei n 47, de 07 de maio de 1857. [Lei orçamentária da Província de São Paulo, 
1857]. Assembleia Legislativa do Estado de São Paulo [Repositório legal]. Disponível em: <http://www.al.sp.gov. br/repositorioAH/Acervo/Alesp/Imperio/Falp 558/PR57 008.pdf $>$. Acesso em: 14 ago. 2017.

PROVÍNCIA DESÃO PAULO. Lei n 16, de 03 de agosto de 1861. [Lei orçamentária da Província de São Paulo, 1861]. Assembleia Legislativa do Estado de São Paulo [Repositório legal]. Disponível em: <https://www.al.sp.gov. br/norma/140030>. Acesso em: 24 nov. 2016.

PROVÍNCIA DE SÃO PAULO. Lei n ${ }^{\circ} 08$, de 19 de maio de 1862. [Lei orçamentária da Província de São Paulo, 1862]. Assembleia Legislativa do Estado de São Paulo [Repositório legal]. Disponível em: <http://www.al.sp.gov. br/repositorioAH/Acervo/Alesp/Imperio/Falp 563/PR62 047.pdf>. Acesso em: 14 ago. 2017.

PROVÍNCIA DE SÃO PAULO. Lei n 30, de 26 de abril de 1864. [Lei orçamentária da Província de São Paulo, 1864]. Assembleia Legislativa do Estado de São Paulo [Repositório legal]. Disponível em: <http://www.al.sp.gov. br/repositorioAH/Acervo/Alesp/Imperio/Falp_564/PR64_038.pdf>. Acesso em: 14 ago. 2017.

PROVÍNCIA DE SÃO PAULO. Lei n 54, de 20 de abril de 1866. [Lei orçamentária da Província de São Paulo, 1866]. Assembleia Legislativa do Estado de São Paulo [Repositório legal]. Disponível em: <http://www:al.sp.gov. br/repositorioAH/Acervo/Alesp/Imperio/Falp 565/PR66 015.pdf>. Acesso em: 14 ago. 2017.

PROVÍNCIA DE SÃO PAULO. Lei n 57, de 18 de abril de 1868. [Lei orçamentária da Província de São Paulo, 1868]. Assembleia Legislativa do Estado de São Paulo [Repositório legal]. Disponível em: <http://www.al.sp.gov. br/repositorioAH/Acervo/Alesp/Imperio/Falp_149/CF68_116.pdf>. Acesso em: 14 ago. 2017.

PROVÍNCIA DE SÃO PAULO. Lei n 93, de 21 de abril de 1870. [Lei orçamentária da Província de São Paulo, 1870]. Assembleia Legislativa do Estado de São Paulo [Repositório legal]. Disponível em: <https://www.al.sp.gov. br/norma/139284>. Acesso em: 24 nov. 2016.

PROVÍNCIA DE SÃO PAULO. Lei n 45, de 01 de abril de 1871. [Lei orçamentária da Província de São Paulo, 1871]. Assembleia Legislativa do Estado de São Paulo [Repositório legal]. Disponível em: <http://www.al.sp.gov. br/repositorioAH/Acervo/Alesp/Imperio/esp-199/PR71-054.pdf>. Acesso em: 14 ago. 2017.

PROVÍNCIA DE SÃO PAULO. Lei n ${ }^{\circ}$ 52, de 24 de abril de 1874. [Lei orçamentária da Província de São Paulo, 1874]. Assembleia Legislativa do Estado de São Paulo [Repositório legal]. Disponível em: <http://www.al.sp.gov. br/repositorioAH/Acervo/Alesp/Imperio/Falp_575/PR74_064.pdf>. Acesso em: 14 ago. 2017.

PROVÍNCIA DE SÃO PAULO. Lei nº 89, de 13 de abril de 1876. [Lei orçamentária da Província de São Paulo, 1876]. Assembleia Legislativa do Estado de São Paulo [Repositório legal]: Disponível em: <http://www.al.sp.gov. br/repositorioAH/Acervo/Alesp/Imperio/esp-064/CF76-104.pdf>. Acesso em: 14 ago. 2017.

PROVÍNCIA DE SÃO PAULO. [Lei orçamentária da Província de São Paulo, 1879]. Assembleia Legislativa do Estado de São Paulo [Repositório legal]. Disponível em: <http://www.al.sp.gov.br/repositorioAH/Acervo/Alesp/ Imperio/esp-071/CF79-057.pdf>. Acesso em: 14 ago. 2017.

PROVÍNCIA DE SÃO PAULO. Lei n ${ }^{0}$ 156, de 20 de abril de 1880. [Lei orçamentária da Província de São Paulo, 1880]. Assembleia Legislativa do Estado de São Paulo [Repositório legal]. Disponível em: <https://www.al.sp.gov. $\mathrm{br} /$ norma/139538>. Acesso em: 24 nov. 2016. 
PROVÍNCIA DE SÃO PAULO. Lei n 92, de 17 de maio de 1883. [Lei orçamentária da Província de São Paulo, 1883]. Assembleia Legislativa do Estado de São Paulo.[Repositório legal]. Disponível em: <http://www.al.sp.gov. br/repositorioAH/Acervo/Alesp/Imperio/esp-080/CF83-103.pdf>. Acesso em: 14 ago. 2017.

PROVÍNCIA DE SÃO PAULO. Lei n 59, de 25 de abril de 1884. [Lei orçamentária da Província de São Paulo, 1884]. Assembleia Legislativa do Estado de São Paulo [Repositório legal]. Disponível em: <http://www.al.sp.gov. br/repositorioAH/Acervo/Alesp/Imperio/Falp_597/PR84_143.pdf>. Acesso em: 14 ago. 2017.

PROVÍNCIA DE SÃO PAULO. Lei n 95, de 11 de abril de 1887. [Lei orçamentária da Província de São Paulo, 1887]. Assembleia Legislativa do Estado de São Paulo [Repositório legal]. Disponível em: <http://www.al.sp.gov. br/repositorioAH/Acervo/Alesp/Imperio/Falp_603/PR87_091.pdf>. Acesso em: 14 ago. 2017.

PROVÍNCIA DE SÃO PAULO. Lei n 107, de 09 de abril de 1889. [Lei orçamentária da Província de São Paulo, 1889]. Assembleia Legislativa do Estado de São Paulo [Repositório legal]. Disponível em: <https://www.al.sp.gov. $\mathrm{br} / \mathrm{norma} / 139364>$. Acesso em: 24 nov. 2016.

ROCHA, Antonio Candido da. Relatório apresentado à Assembleia Legislativa Provincial de S. Paulo pelo Presidente da Provincia, o Exm. Sr. Dr. Antonio Candido da Rocha. São Paulo: Typographia Americana, 1870. Disponível em: <http://brazil.crl.edu/bsd/bsd/1011/000002.html>. Acesso em: 26 nov. 2016.

SILVA, Antonio da Costa Pinto. Relatório apresentado à Assembleia Legislativa Provincial de S. Paulo pelo Presidente da Província, o Exm. Sr. Dr. Antonio da Costa Pinto Silva. São Paulo: Typographia Americana, 1871. Disponível em: <http://brazil.crl.edu/bsd/bsd/1012/000002.html>. Acesso em: 26 nov. 2016.

SOARES, Francisco de Carvalho. Relatório apresentado à Assembleia Legislativa Provincial de S. Paulo na Abertura da 2.a Sessão da 24. a Legislatura pelo Presidente, Conselheiro Francisco de Carvalho Soares Brandão. S. Paulo: Typographia do Ypiranga, 1883. Disponível em: <http://brazil.crl.edu/bsd/bsd/1027/000002. html>. Acesso em: 27 nov. 2016.

TORRES, José Joaquim Fernandes. Discurso com que o llustríssimo e Excelentíssimo Senhor Senador José Joaquim Fernandes Torres, Presidente da Província de São Paulo, abriu a Assembleia Legislativa Provincial. São Paulo: Typographia Imparcial de Joaquim Roberto de Azevedo Marques, 1860. Disponível em: < http:// brazil.crl.edu/bsd/bsd/997/000002.html>. Acesso em: 26 nov. 2016.

\section{Livros, artigos e outras referências bibliográficas:}

BASSANEZI, Maria Silvia C. Beozzo (Org.). São Paulo do passado: dados demográficos (1836-1920). Campinas: Nepo/Unicamp, 1998. Disponível em: <http://www.nepo.unicamp.br/publicacoes/censos.php>. Acesso em: 14 ago. 2017.

BEIGUELMAN, Paula. A formação do povo no complexo cafeeiro. Aspectos políticos. São Paulo: Pioneira, 1977. 
CANABRAVA, Alice P. O desenvolvimento da cultura do algodão na Província de São Paulo (1867-1875). São Paulo: Edusp, 2011.

COSER, Ivo. Visconde do Uruguai: Centralização e Federalismo no Brasil, 1823-1866. Belo Horizonte: UFMG, 2008.

COSTA, Iraci del Nero da (compilador). Pesos e medidas no período colonial brasileiro: denominações e relações. Boletim de História Demográfica, São Paulo, v. 1, n. 1, 1994.

DOLHNIKOFF, Miriam. Elites regionais e a construção do Estado Nacional. In: JANCSÓ, István (Org.). Brasil: formação do estado e da nação. São Paulo: Hucitec, 2003. p. 431-468.

DOLHNIKOFF, Miriam. O pacto imperial: origens do federalismo no Brasil do século XIX. São Paulo: Globo, 2005.

LUNA, Francisco Vidal; KLEIN, HerbertS. Nota a respeito de medidas de grãos utilizadas no período colonial e as dificuldades para a conversão ao sistema métrico. Boletim de História Demográfica, São Paulo, v. 8, n. 21, mar. 2001. Disponível em: <https://www.researchgate.net/publication/266094538>. Acesso em: 7 fev. 2017.

LUNA, Francisco Vidal. Observações sobre os dados de produção apresentados por Müller. Boletim de História Demográfica, São Paulo, v. 9, n. 24, jan. 2002. Disponível em: <http://historia_demografica.tripod.com/pesquisadores/paco/pdf-paco/ar50.pdf>. Acesso em: 7 fev. 2017.

MILLIET, Sergio. Roteiro do café. Análise histórico-demográfica da expansão cafeeira no Estado de São Paulo. São Paulo: Escola de Sociologia e Política de São Paulo, 1938.

MÜLLER, Daniel Pedro. Ensaio d’um quadro estatístico da Província de São Paulo. São Paulo: Coverno do Estado, 1978.

NOZOE, Nelson Hideiki. São Paulo: economia cafeeira e urbanização. São Paulo: IPE-USP, 1984.

NOZOE, Nelson; VALENTIN, Agnaldo; MOTTA, José Flávio; ARAÚjO, Maria Lucília V.; COSTA, Iraci del Nero da; LUNA, Francisco Vidal. Brasil: breves comentários sobre algumas séries referentes à taxa de câmbio. São Paulo: [s.n.],2004. [Mimeo].

PETRONE, Maria Thereza Schorer. A lavoura canavieira em São Paulo. São Paulo: Difusão Europeia do Livro, 1968.

RIBEIRO, Maria Alice Rosa. Condições de trabalho na indústria têxtil paulista (1870-1930). São Paulo: Hucitec, 1988.

SYLOS, Honório de. Introdução. In: MÜLLER, Daniel Pedro. Ensaio d'um quadro estatístico da Província de São Pau10.São Paulo: Governo do Estado, 1978. p. 7-17.

TESSITORE, Viviane. As fontes de riqueza pública. Tributos e administração tributária na. Província de São Paulo (1832-1892). 1995. Dissertação (Mestrado em História Social)-Universidade de São Paulo, São Paulo. 1995. 